\title{
Assessment of occupational exposure from radon in the newly formed underground tourist route under Książ castle, Poland
}

\author{
Lidia Fijałkowska-Lichwa ${ }^{1}$ (D) $\cdot$ Tadeusz A. Przylibski $^{2}$
}

Received: 5 October 2020 / Accepted: 8 March 2021 / Published online: 19 March 2021

(c) The Author(s) 2021

\begin{abstract}
In the present study, ${ }^{222} \mathrm{Rn}$ activity concentrations in a newly formed underground tourist route under Książ castle, Poland, were investigated for periods undisturbed and disturbed by construction works. This preliminary assessment is based on the almost 3-year long continuous measurements (28 Oct. 2016-02 Jul. 2019) done with an SRDN-3 instrument. In detail described are radon concentrations for periods of renovation (11 Aug. 2018-10 Oct. 2018), opening (15 Oct. 2018-10 Apr. 2019) and operation and monitoring (11 Apr. 2019-02 Jul. 2019) of the facility. It was observed that after the termination of construction work, when natural ventilation returned to the state preceding this work, the absolute values of radon activity concentration decreased. The mean annual radon concentrations were higher than the reference level of radon concentration in underground spaces recommended by IAEA, ICRP, and by the EU Council Directive for workplaces. They reached $1179 \mathrm{~Bq} / \mathrm{m}^{3}$ and $943 \mathrm{~Bq} / \mathrm{m}^{3}$ in 2017 and 2018, respectively. Cyclically recurring daily changes in radon concentrations occurred only in April and October (so-called transitional periods) and only outside the period of construction work. The results confirmed; however, that these changes need not be considered when planning the work in the tunnel. The minimum effective dose rate from radon exposure occurs in colder periods of the year, from November to the end of March, where the mean effective dose rate value was found to be $0.0003 \mathrm{mSv} / \mathrm{h}$. In contrast, the maximum dose rate of $0.014 \mathrm{mSv} / \mathrm{h}$ was observed from April to August.
\end{abstract}

Keywords Radon measurements $\cdot$ Radiation protection $\cdot$ Effective dose $\cdot$ Workplace $\cdot$ Construction works $\cdot$ Ventilation

\section{Introduction}

In Poland, like in other countries, the increased ionising radiation in underground spaces is related to the accumulation of radon-a radioactive gas (Chibowski and Komosa 2001; Skowronek et al. 2004; Fijałkowska-Lichwa and Przylibski 2016; Przylibski et al. 2017; Alvarez-Gallego et al. 2015; Bekteshi et al. 2017; Chao et al. 1997; Da Silva et al. 2011; Cucoş Dinu et al. 2017; Dueñas et al. 2011; Dumitru et al.

Lidia Fijałkowska-Lichwa

Lidia.Fijalkowska-Lichwa@pwr.edu.pl

Tadeusz A. Przylibski

Tadeusz.Przylibski@pwr.edu.pl

1 Faculty of Civil Engineering, Wrocław University of Science and Technology, Wybrzeże S. Wyspiańskiego 27, 50-370 Wrocław, Poland

2 Faculty of Geoengineering, Mining and Geology, Wrocław University of Science and Technology, Wybrzeże S. Wyspiańskiego 27, 50-370 Wrocław, Poland 2015a, b, 2016; Espinosa et al. 2013; Font et al. 2008; Gillmore et al. 2002, 2005; Korhonen et al. 2000; Lario et al. 2006; Liu et al. 2018; Özen et al. 2019; Perrier et al. 2007; Richon et al. 2005; Shahrokhi et al. 2017; Trevisi et al. 2012; Wang et al. 2019; Vaupotič et al. 2001; Zhou et al. 2019). Existing and newly opened underground facilities of various types and functions are becoming workplaces for a growing number of people. These sites are very often restored historic sites (including technological or military heritage sites like underground fortresses, tunnels, shelters, pyramids, tombs, castles, wineries) where underground tourist routes are organized. As a result, more and more peoplemainly service staff and guides, sometimes speleologists or researchers-are working in conditions of increased exposure to ionising radiation from radon (mainly from the radioisotope ${ }^{222} \mathrm{Rn}$ ) and its, also radioactive, progeny (Przylibski and Fijałkowska-Lichwa 2017a, 2017b, 2018a, b, c, d, 2019; Hafez and Hussein 2001; Hafez et al. 2003; Martinez et al. 2005; Vaupotič 2008; Abdelzaher 2011; Youssef and Hanfi 2019; Wysocka 2011; Gruber et al. 2011; Walczak et al. 
2017; Ambrosino et al. 2020a, b). In Poland, increasingly underground tourist facilities are being created in the area of Lower Silesia, especially in the Sudetes and the Sudetic Foreland. Owing to their geological structure, these areas are considered so-called radon prone areas. This is related to the occurrence of radium and uranium-rich crystalline rocks lying directly on the surface or at small depths (Strzelecki et al. 1993, 1994; Wołkowicz 2007; Przylibski 2004, 2015, 2018). Formed in the natural uranium-radium radioactive series as a direct product of the alpha decay of ${ }^{226} \mathrm{Ra},{ }^{222} \mathrm{Rn}$, being a noble gas, is released from the rocks in which it has been formed. Released from rocks, ${ }^{222} \mathrm{Rn}$ may accumulate in the air of underground engineering structures. The increased level of ${ }^{222} \mathrm{Rn}$ activity concentration is partly due to the effective isolation of these structures from the atmosphere and the consequent ineffective ventilation. Moreover, ${ }^{222} \mathrm{Rn}$ penetrates inside underground structures from the surrounding rocks due to numerous fractures and fissures in these rocks as well as voids, pores and cracks in the construction materials and structural elements (supports) of the workings. $\mathrm{As}^{222} \mathrm{Rn}$ accumulates inside a structure, it may reach very high concentrations (Fijałkowska-Lichwa 2014, 2016, 2020; Fijałkowska-Lichwa and Przylibski 2011, 2016, 2020; Olszewski et al. 2005, 2015; Przylibski 1996, 1999, 2015, 2018; Tchorz-Trzeciakiewicz and Solecki 2011; Tchorz-Trzeciakiewicz and Parkitny 2015).

Most countries in Europe and the rest of the world have introduced reference levels for ${ }^{222} \mathrm{Rn}$ activity concentrations in public underground facilities, including underground workplaces, based on the recommendations of various specialized international organizations like the International Atomic Energy Agency (IAEA 1996,2003,2014), the International Commission on Radiological Protection (ICRP 1993,1996,2011,2014,2017) and the World Health Organisation (WHO 2009). The reference levels recommended and used in radiological protection were specified as the level of dose or risk or radionuclide concentration above protective (both preventive and corrective) actions should be planned and optimized. Optimization should be applied as appropriate, also below the reference level and not only above (ICRP 2014).

Recently, ICRP revised the upper value for the reference level for radon gas in dwellings from 600 to $300 \mathrm{~Bq} / \mathrm{m}^{3}$ (ICRP 2011,2014). The effective doses implied by radon concentrations close to this reference level are close to the level of $10 \mathrm{mSv}$ per year for exposure in a dwelling. As an effective dose limit for occupational exposure, ICRP recommended a value of $20 \mathrm{mSv}$ per year averaged over defined 5 -year periods ( $100 \mathrm{mSv}$ in 5 years), with the further provision that the effective dose should not exceed $50 \mathrm{mSv}$ in any single year (ICRP 2011,2014).

For radon gas in dwellings, ICRP recommends the value of $300 \mathrm{~Bq} / \mathrm{m}^{3}$ as the upper value of the reference level. ICRP also recommends to use the same upper value of $300 \mathrm{~Bq} / \mathrm{m}^{3}$ as the reference level for radon gas in mixed-use buildings with access for both members of the public and workers, and in workplaces without access for public. However, in any case, national authorities are responsible that the risk due to radiation exposure is kept as low as reasonably achievable, taking societal and economic considerations into account. This includes the control of radiation sources and the establishment of national reference levels (ICRP 2011,2014).

The ICRP recommendations were taken into account by IAEA. The IAEA established a strategy for protection against exposure due to ${ }^{222} \mathrm{Rn}$ at workplaces, including an appropriate reference level for ${ }^{222} \mathrm{Rn}$, set at an annual average activity concentration of ${ }^{222} \mathrm{Rn}$ of $1000 \mathrm{~Bq} / \mathrm{m}^{3}$ (IAEA 2014). Regulations for maintaining stability in national standards have been improved and included in the safety standards issued by the IAEA in their regulatory programmes (IAEA 2014).

The World Health Organization reduced the reference level for ${ }^{222} \mathrm{Rn}$ and recommended a value of $100 \mathrm{~Bq} / \mathrm{m}^{3}$. However, the WHO added that if this level cannot be implemented because of specific geological and house construction conditions, the chosen reference level should at least not exceed $300 \mathrm{~Bq} / \mathrm{m}^{3}$ (WHO 2009).

The European Union has adopted a mandatory reference level of $300 \mathrm{~Bq} / \mathrm{m}^{3}$ for the mean annual radon concentration at workplaces in its 27 member states (EU Council Directive 2013). It is emphasized that workplaces where the mean annual ${ }^{222} \mathrm{Rn}$ activity concentration can be higher than $300 \mathrm{~Bq} / \mathrm{m}^{3}$ include underground spaces.

In Poland, issues related to ${ }^{222} \mathrm{Rn}$ in residential buildings and at work places are regulated by Atomic Law (Law 2000). After the amendment of this law in compliance with EU regulations (EU Council Directive 2013), a reference level of $300 \mathrm{~Bq} / \mathrm{m}^{3}$ indicated as the average annual radon activity concentration at home and at workplaces was implemented (Law 2000).

The aim of the present work was to address the problem of occupational exposure to ionising radiation in underground engineering structures, including tourist attractions. To this aim, the exposure of workers (mainly service staff and guides, sometimes also speleologists or researchers) to ionising radiation from ${ }^{222} \mathrm{Rn}$ and its decay products was assessed in a newly opened underground facility at Książ castle, Poland, being both an example underground workplace and an underground tourist attraction. Changes in ${ }^{222} \mathrm{Rn}$ activity concentration in the underground complex were investigated prior to launching the construction works, during these works, and after opening the facility to visitors. Such an approach has not been presented in the literature yet.

Measurements of ${ }^{222} \mathrm{Rn}$ at Książ castle are being carried out continuously since 2014 . At the beginning, these measurements were carried out in an underground laboratory, 
while they have been extended since 2016 to the part of the underground, which is being developed for tourists. The results of the present study allowed the establishment of a database on ${ }^{222} \mathrm{Rn}$ concentrations at the studied location, which can be used as a supporting tool (main source of information) when the first construction work will be carried out on the site by private owners and local self-government authorities.

\section{Materials and methods}

\section{Location-general characteristics}

The study was conducted in an underground complex under one of the largest castles in Poland. This complex was not accessible to visitors until 15 October 2018. The studied tunnels are part of the Riese complex built by the German paramilitary organization Todt in the Sowie (Owl) Mountains during World War II in 1943-1945. The intended function of these tunnels has not been fully explained yet (Lamparska 1998; Kalarus 2001; Kruszyński 2004; Pawlikowska 2008).
Książ castle is located in the Sudetes, one of the Central European Variscan mountain ranges. The castle is situated within the central part of Świebodzice Basin. This basin is intersected by a dense network of faults. Other large tectonic dislocations form its borders, separating Świebodzice Basin from the neighbouring geological units of the Sudetes. The faults of Struga (in the south), Szczawienko (in the west) and the Sudetic Marginal Fault (in the east) separate Świebodzice Basin from the Intra-Sudetic Basin, the gneiss massif of the Sowie Mountains and the Pre-Sudetic Block respectively. To the north, rocks of the metamorphic Kaczawa Complex are overthrust by the deposits of Świebodzice Basin (Fig. 1; Teisseyre 1956; Porębski 1981; Wojewoda 2016a, b).

Since 1991, the castle has been managed by Zamek Książ partnership in Wałbrzych in collaboration with the Municipality of Wałbrzych. Since 2015, the castle vaults have been used jointly by the Municipality of Wałbrzych and the Polish Academy of Sciences (PAN). According to the bilateral agreement, part of the vaults house the Geodynamic Laboratory of the Space Research Centre (LG CBK). This part represents a separate area excluded from tourist use and set

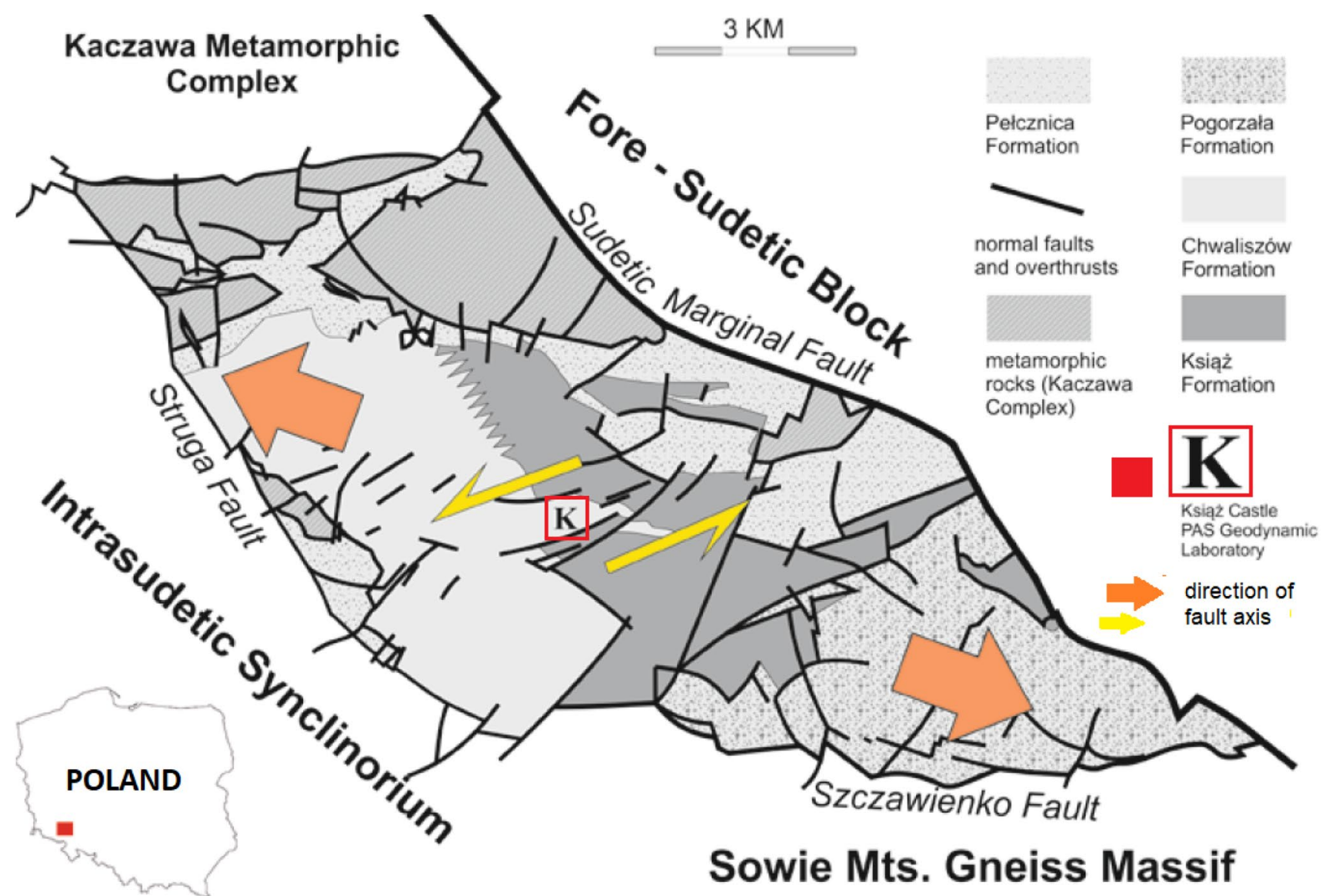

Fig. 1 Simplified geological map of Świebodzice Basin with the research site marked as "K" (based on Kaczorowski and Wojewoda 2011); Bottom left corner-location of Świebodzice Basin in Poland 
aside for the use of the Polish Academy of Sciences (Kaczorowski 1999a, b, 2009; Kaczorowski et al. 2012, 2018; Kasza et al. 2014, 2018). Since 2014, the Space Research Centre of the Polish Academy of Sciences has been cooperating with Wrocław University of Science and Technology to conduct joint measurements of radon activity concentrations and, in parallel, of any changes in the rock mass kinetics (Fijałkowska-Lichwa nad Przylibski 2016; Przylibski et al. 2020).

The work on the construction of the underground tourist route started on 14 March 2018. The basic work was completed in July 2018 by excavating the staircase shafts and lining them with concrete. In August 2018, adapting the underground complex for tourist use started. At the beginning of October 2018, the first entrance to the object (main entrance) with a staircase measuring $1.2 \mathrm{~m}^{2}$ in diameter, located close to entrance no. 2 in the western part of the complex was opened. From August 2018 to mid-October 2018, the system of natural (gravitational) ventilation was adjusted. To increase air flow in the working areas while work was carried out inside the staircase, the doors were opened between
9 a.m. and 6 p.m. The first stage of construction work was completed by the middle of October 2018. The second stage started on 15 October 2018, when the underground tourist route was festively opened to visitors. The last stage of the whole project, i.e.:-operation and monitoring of the route, started on 11 April 2019.

\section{Ventilation conditions}

Before the work on the construction of an underground tourist route under Książ castle started, the existing system of underground working places had been relatively well isolated from the atmosphere. Air exchange was possible through natural fractures in the orogen and the door closing the outlet of adit no. 2 (cf. Fig. 2). During the tourist route preparation, the isolation of the space from the atmosphere was partly reduced. For this, two shafts for staircases were excavated near the outlets of adit no. 2 and no. 3 , and a ventilation window was opened opposite to the original entrance to and exit-in the partly blocked outlet of adit no. 4 . Hence,

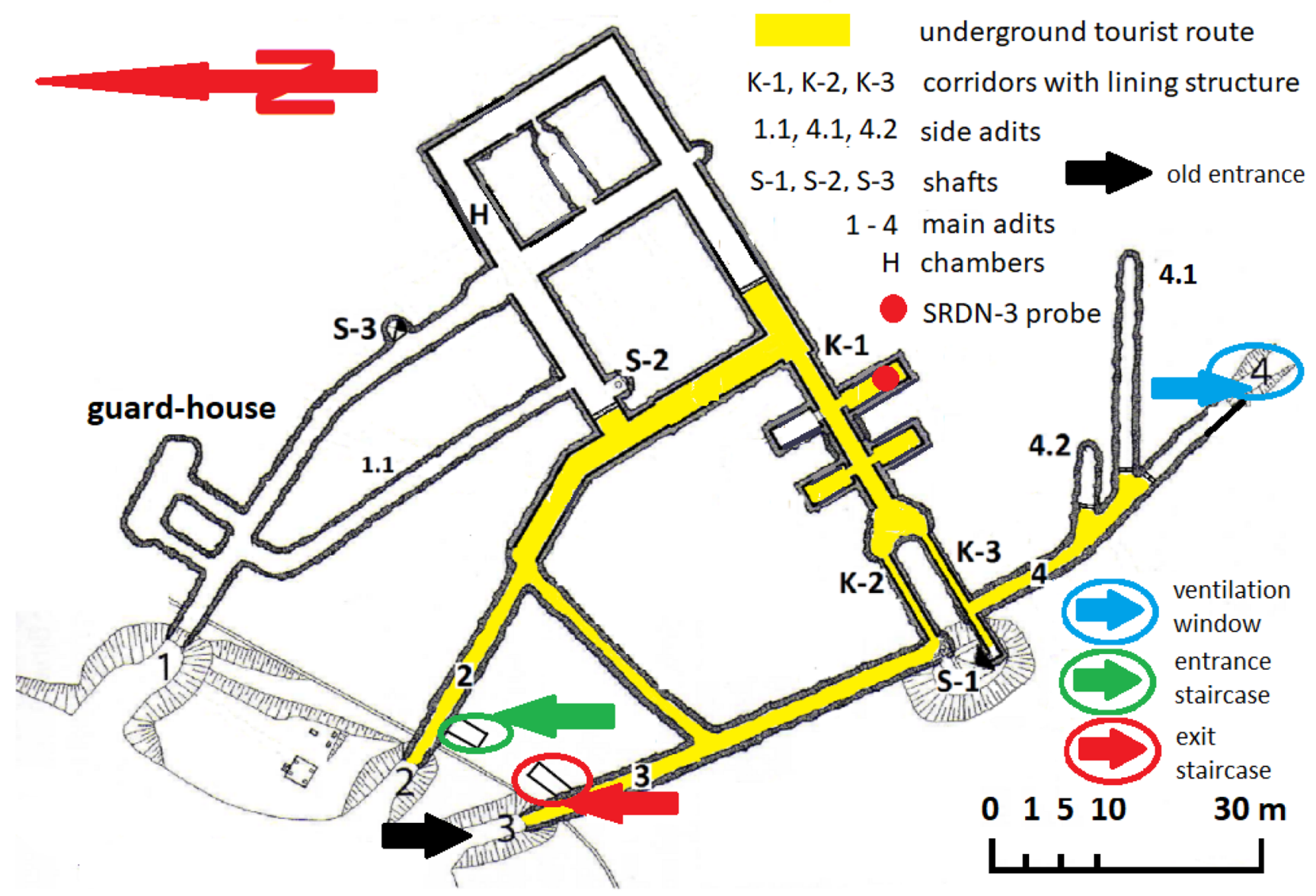

Fig. 2 Site plan of the tourist route below the forecourt of Książ castle; red filled circle-location of SRDN-3 probe; figure modified based on the materials provided by facility managers 
natural longitudinal ventilation (Fig. 3), without using fans, was employed (Fig. 3a).

Thus, at that time, the research site was not equipped with a mechanical ventilation system (Fig. 3b), and ventilation of the tourist part of the underground complex occurred naturally. Air exchange occurs due to the pressure difference between the inlet (entrance) and the outlet (exit) of the complex - the staircase shafts-and the opened ventilation window in the outlet of adit no. 4 (Fig. 2), and due to any temperature difference between the interior of the complex and the outer atmosphere. The outlet of adit no. 4 is located about $15 \mathrm{~m}$ below the door, closing the staircases on the entrance and exit shafts. The temperature inside the working area is almost constant at $+10.2^{\circ} \mathrm{C}$. Thus, the air exchange between the underground complex and the atmosphere is caused by advective and convective air circulation. Natural ventilation conditions improve or deteriorate depending on the prevailing direction of wind. Typically, south-eastern wind pushes the atmospheric air into adit no. 4 (Fig. 2).

Convective air movement is the main mechanism of natural ventilation in the complex from autumn to spring, when distinctly warmer air containing radon is transported from the working areas to the atmosphere. In the transitional periods occurring in spring (April) and autumn (October), when the atmospheric air temperature oscillates around $+10{ }^{\circ} \mathrm{C}$, convective air exchange with the atmosphere is triggered only at night (from the afternoon, through the evening, until the late morning of the following day). In contrast, in summer, the cool air inside the working areas stagnates together with radon accumulating in the spaces of the underground tourist route. Natural ventilation is enhanced by depression resulting from air density differences. This causes a change in the air flow direction in summer as compared to winter. In the warmer season, mainly in summer, the air flows from the north-west to the south, i.e., from the staircase to the outlet of adit no. 4. In winter, air exchange occurs in the opposite direction, and the air is directed from the ventilation window in adit no. 4 to the staircases at the entrance to and exit from the complex (by adit no. 2 and no. 3), i.e., from south to north-west (Fig. 2). The ventilation window in the outlet of adit no. 4 is opened to adjust the ventilation of the working area, especially when a strong wind blows from the south or south-east and forces an atmospheric air stream straight into adit no. 4 (Fig. 2). The air stream that enters underground through the ventilation window in adit no. 4 is directed up the staircase in the shaft next to adits 2 and 3 and then, about $15 \mathrm{~m}$ higher is released into the atmosphere (Fig. 2).

\section{Radon measurements}

To monitor ${ }^{222} \mathrm{Rn}$ activity concentrations, an SRDN-3 probe-equipped with a semi-conductor detector was used. This device has been used for nearly 10 years in demanding conditions, especially in environments with prolonged or permanent persistence of a relative humidity of $100 \%$. The structure and operating principle of the device is described in detail in Przylibski et al. (2010). The SRDN-3 was calibrated at the Nuclear Physics Institute
Fig. 3 Example plan of natural longitudinal ventilation without fans (a) prevalent in winter and mechanical ventilation with a fan in a staircase (b) applicable in the underground tourist route in Książ castle (based on Nawrat and Napieraj 2005; Nawrat et al. 2012)

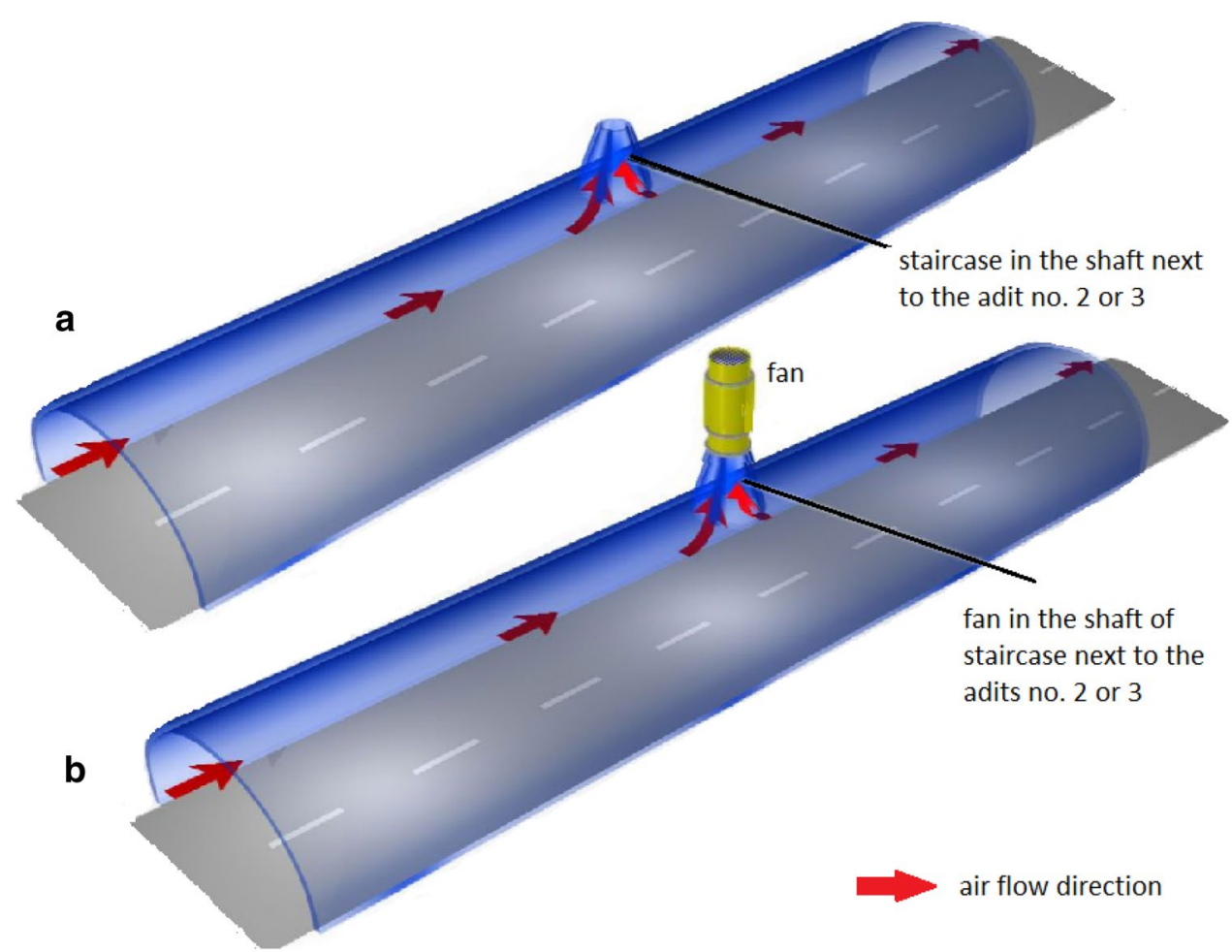


of the Polish Academy of Sciences in Krakow, Poland, involving certified measuring methods and including various ${ }^{222} \mathrm{Rn}$ activity concentrations in a radon chamber. A radon monitor AlphaGUARD PQ2000PRO was used as a reference device (Przylibski et al. 2010).

In terms of the ${ }^{222} \mathrm{Rn}$ activity concentration, the detection limit after calibration of the detector was close to $80 \mathrm{~Bq} / \mathrm{m}^{3}$. The maximum measurable ${ }^{222} \mathrm{Rn}$ activity concentration was established by the producer-the Institute of Nuclear Chemistry and Technology (IChTJ) in Warsaw-as $157 \mathrm{MBq} / \mathrm{m}^{3}$. This is considerably higher than the values observed so far in underground spaces, i.e., about 50 times higher than concentrations typically observed in the environment (approximately several $\mathrm{MBq} / \mathrm{m}^{3}$ ). Typically, measurement uncertainties (mean value \pm SE) for concentrations close to the detection limit $(80-100 \mathrm{~Bq} /$ $\mathrm{m}^{3}$ ) did not exceed $24 \%$, and were between 7 and $12 \%$ for ${ }^{222} \mathrm{Rn}$ activity concentrations of the order of $500-1000 \mathrm{~Bq} /$ $\mathrm{m}^{3}$, and less than $5 \%$ for ${ }^{222} \mathrm{Rn}$ activity concentrations of 5000-10,000 Bq/ $\mathrm{m}^{3}$ (Przylibski et al. 2010).

Measurements of ${ }^{222} \mathrm{Rn}$ activity concentrations were carried out in the working areas lying at the depth of $50 \mathrm{~m}$ below the level of the castle forecourt. The underground system is composed of four adits interconnected by numerous corridors and chambers (Fig. 2). To identify the highest ${ }^{222} \mathrm{Rn}$ activity concentrations, measurements were performed at the point with the lowest expected ventilation, i.e., the most distant from the entrance to and exit from the underground tourist route (Fig. 2). Because the ${ }^{222} \mathrm{Rn}$ concentrations measured at this point represent a worst-case scenario, the corresponding effective doses will probably overestimate somewhat the exposure of workers and tourists.

The SRDN-3 device was placed left of the main gallery fork (K-1), in a concrete-lined chamber which is a part of the main traffic route (Fig. 2). The cross-section of the chamber resembles an ellipse. Its length, measured from the entrance, is about $15 \mathrm{~m}$, the width is about $3.7 \mathrm{~m}$, and the height is about $4.8 \mathrm{~m}$. The chamber is made of reinforced concrete. The SRDN-3 device was placed at a height of about $1 \mathrm{~m}$ above the tunnel floor. The registered counts were stored at 1-h intervals and converted to ${ }^{222} \mathrm{Rn}$ activity concentrations with the use of a linear calibration equation (Przylibski et al. 2010).

The impact of the reinforced concrete lining structure, which was employed to stabilize the underground structure, on the levels of ${ }^{222} \mathrm{Rn}$ activity concentrations recorded inside the working areas of Książ castle was discussed by Fijałkowska-Lichwa (2020). It was shown that the reinforced concrete lining did not affect the character (seasonal, daily) of changes in ${ }^{222} \mathrm{Rn}$ activity concentration, neither in the long term (years) nor in the short term (hours or days). Rather, it should be seen as a barrier that reduces the porosity of the rocks and limits the radon flux from the surrounding rocks into the tourist corridors (Fijałkowska-Lichwa 2020).

In the period between 12 January 2017 and 04 April 2017, the measurements were suspended because of a failure of the SRDN-3 detector. The ${ }^{222} \mathrm{Rn}$ activity concentrations were taken from a detector operating near the underground tourist route, inside the CBK PAN geodynamic laboratory. These concentrations were included in the present analyses and used for the interpretation of ${ }^{222} \mathrm{Rn}$ concentrations in the tourist part of the underground complex at Książ.

\section{Effective dose calculation}

To estimate the mean annual effective dose $E$ (mSv/year) from radon and its decay products $\left({ }^{218} \mathrm{Po},{ }^{214} \mathrm{~Pb},{ }^{214} \mathrm{Bi}\right.$ and ${ }^{214} \mathrm{Po}$ ) received by people working in the studied underground workplaces, UNSCEAR guidelines (2000) were employed. Specifically, the effective dose $E$ was calculated as a sum of two components: the effective dose resulting from inhalation of ${ }^{222} \mathrm{Rn}$ and its daughter products (expressed in $\mathrm{mSv}$ ) and the effective dose resulting from ${ }^{222} \mathrm{Rn}$ intake (also expressed in $\mathrm{mSv}$ ) (Eq. 1).

$E=C \cdot F \cdot E_{\mathrm{iCF}}^{+} C \cdot E_{\mathrm{bCF}}$,

where $C$ is ${ }^{222} \mathrm{Rn}$ activity concentration in air $\left(\mathrm{Bq} / \mathrm{m}^{3}\right)$, and $F$ is the radioactive equilibrium factor. The value of $F$ was adopted as 0.4 - the level proposed for indoor workplaces and tourist caves included in Publication 137 (ICRP 137 2017). Furthermore, $E_{\mathrm{iCF}}$ is the dose conversion factor for inhalation, with the value of $9.0\left(\mathrm{nSv} / \mathrm{Bq} \bullet \mathrm{h} / \mathrm{m}^{3}\right)$ and $E_{\mathrm{bCF}}$ is the dose conversion factor for ${ }^{222} \mathrm{Rn}$ ingestion and its dissolution in blood, with the value of $1.7(\mathrm{nSv} / \mathrm{Bq} \bullet \mathrm{h} /$ $\mathrm{m}^{3}$ ), adopted from UNSCEAR guidelines $(2000,2019)$.

All effective dose $(E)$ values calculated with Eq. 1 are related to $1 \mathrm{~h}$ of work or $1 \mathrm{~h}$ spent inside the facility. To compare this with the annual effective dose limits set in Appendix 4 to Atomic Law of 29 November 2000 (Law 2000), these values were multiplied with the number of hours an individual worker spent in the working areas of the prepared tourist route in the underground complex of Książ castle in 2018 (Tables 1 and 2). The ICRP proposed also a value of 0.2 as the equilibrium factor $F$ for mines (ICRP 137 2017; Annex A, Table A.11). Taking this value instead of the value of 0.4 mentioned above, the effective dose values were calculated with Eq. 1 would be a factor of 2 smaller than those shown in Tables 1 and 2.

In Poland, the annual effective dose limit for employees is $20 \mathrm{mSv} /$ year (Law 2000, item 1792, app. 4, sections 1.1 and 1.4) and $1 \mathrm{mSv}$ per calendar year for the general public (Law 2000, item 1792, app. 4, section 3). 


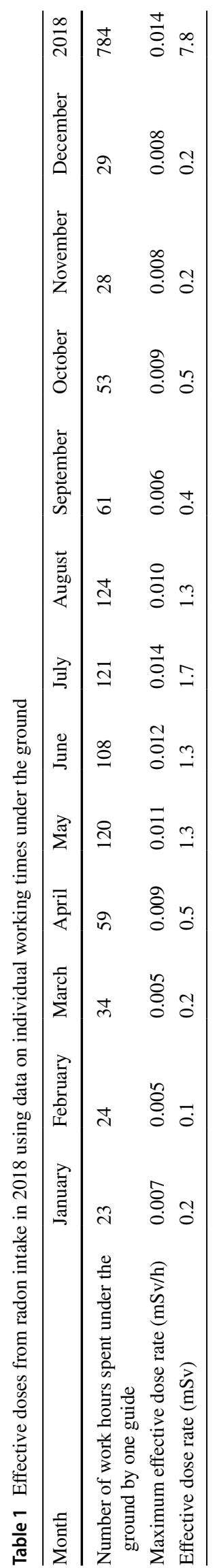

Results and discussion

\section{Seasonal changes in ${ }^{222} \mathrm{Rn}$ concentrations}

Seasonal variations are well known and characteristic for underground spaces well isolated from the atmosphere (Ambrosino et al. 2019). In Poland, this phenomenon has already been observed in many underground spaces, such as the publicly accessible sites at Kletno, Kowary and Złoty Stok, as well as the CBK PAN Geodynamic Laboratory at Książ (Przylibski 1996, 1999, 2001; Przylibski and Ciężkowski 1999; Fijałkowska-Lichwa 2014, 2016; Fijałkowska-Lichwa and Przylibski 2016, 2020).

In the context of the present study, seasonal changes in ${ }^{222} \mathrm{Rn}$ activity concentration occurred throughout all measurement periods, but their course was varied in years disturbed (2018) and undisturbed (2017) by construction works, respectively (Figs. 4 and 5). The analyses performed as part of the present study also took into account all stages of the study route creation (Fig. 6).

In 2018 , the ${ }^{222} \mathrm{Rn}$ activity concentrations decreased slowly but steadily throughout the year, from 1200 to $700 \mathrm{~Bq} / \mathrm{m}^{3}$ (Fig. 4). The amplitudes of seasonal changes were comparable throughout the year 2018 and fell within the range of $100-300 \mathrm{~Bq} / \mathrm{m}^{3}$ (Fig. 4). This was due to the ongoing construction works resulting in an increased ventilation of the complex. At the first stage of tourist route creation (11 August 2018 to 14 October 2018), the course of changes in ${ }^{222} \mathrm{Rn}$ activity concentration was largely influenced by a change in the intensity and volume of the air stream flowing through the underground complex. This was related to typical seasonal changes, additionally enhanced by increased ventilation intensity caused by the opening of staircases near adit no. 2 and no. 3 during the facility working hours (9:00-18:00) (Figs. 4, 5, 6). At the second stage (15 October 2018 to 10 April 2019), the registered mean values of ${ }^{222} \mathrm{Rn}$ activity concentration remained at a practically stable level of $750 \mathrm{~Bq} / \mathrm{m}^{3}$. They also showed small yet irregular changes of $50-100 \mathrm{~Bq} / \mathrm{m}^{3}$ above or below the mean value. Such a course of change was significantly affected by stable (fixed) conditions of intense airing (natural convective ventilation) of the facility (Fig. 6). At the last stage (11 April 2019 to 2 July 2019) ${ }^{222} \mathrm{Rn}$ activity concentrations showed irregular yet large fluctuations characteristic of the so-called transitional period (Fig. 6). The amplitude of these changed ranged from 50 to $200 \mathrm{~Bq} / \mathrm{m}^{3}$ in relation to the mean value (Fig. 6). Between May and July 2019, the concentrations increased from the average level of 800 to slightly more than $1100 \mathrm{~Bq} / \mathrm{m}^{3}$ (Figs. 6 and 7).

In 2017 , undisturbed by construction works, the changes in ${ }^{222} \mathrm{Rn}$ activity concentrations looked different. 
Table 2 Effective doses from intake of radon and its decay products received in selected measurement periods by people spending $1 \mathrm{~h}$ in the working areas of the underground tourist route at Książ castle

\begin{tabular}{|c|c|c|c|c|c|}
\hline \multirow[t]{2}{*}{ Measurement period } & \multirow{2}{*}{$\begin{array}{l}\text { Number of hourly } \\
\text { measurements }\end{array}$} & \multicolumn{4}{|l|}{ Effective dose rates } \\
\hline & & $\begin{array}{l}\text { Average } \pm \text { standard } \\
\text { error }(\mathrm{mSv} / \mathrm{h})\end{array}$ & $\begin{array}{l}\text { Standard deviation } \\
(\mathrm{mSv} / \mathrm{h})\end{array}$ & $\begin{array}{l}\text { Maximum } \\
(\mathrm{mSv} / \mathrm{h})\end{array}$ & Minimum $(\mathrm{mSv} / \mathrm{h})$ \\
\hline $01.01 .2017-31.12 .2017$ & 8675 & $0.004 \pm 0.00002$ & 0.002 & 0.01 & 0.0005 \\
\hline $01.01 .2018-31.12 .2018$ & 8754 & $0.004 \pm 0.00001$ & 0.001 & 0.01 & 0.0003 \\
\hline 28.10.2016-02.07.2019 & 23,370 & $0.004 \pm 0.00001$ & 0.002 & 0.01 & 0.0003 \\
\hline 01.01.-31.01.2017 & 744 & $0.003 \pm 0.00004$ & 0.001 & 0.006 & 0.0005 \\
\hline 01.01.-31.01.2018 & 744 & $0.004 \pm 0.00004$ & 0.001 & 0.008 & 0.001 \\
\hline 01.01.-31.01.2019 & 744 & $0.003 \pm 0.00003$ & 0.0009 & 0.006 & 0.0004 \\
\hline 01.02.-28.02.2017 & 672 & $0.002 \pm 0.00003$ & 0.0007 & 0.005 & 0.0006 \\
\hline 01.02.-28.02.2018 & 672 & $0.004 \pm 0.00004$ & 0.001 & 0.008 & 0.002 \\
\hline 01.02.-28.02.2019 & 672 & $0.003 \pm 0.00003$ & 0.0009 & 0.007 & 0.0004 \\
\hline 01.03.-31.03.2017 & 744 & $0.003 \pm 0.00003$ & 0.0007 & 0.005 & 0.0009 \\
\hline 01.03.-31.03.2018 & 744 & $0.004 \pm 0.00004$ & 0.0011 & 0.007 & 0.0009 \\
\hline 01.03.-31.03.2019 & 744 & $0.003 \pm 0.00003$ & 0.0009 & 0.006 & 0.0003 \\
\hline 01.04.-30.04.2017 & 638 & $0.005 \pm 0.00005$ & 0.001 & 0.009 & 0.002 \\
\hline 01.04.-30.04.2018 & 718 & $0.004 \pm 0.00004$ & 0.001 & 0.007 & 0.001 \\
\hline 01.04.-30.04.2019 & 720 & $0.003 \pm 0.00003$ & 0.0009 & 0.006 & 0.0006 \\
\hline 01.05.-31.05.2017 & 744 & $0.006 \pm 0.00005$ & 0.001 & 0.011 & 0.002 \\
\hline 01.05.-31.05.2018 & 744 & $0.004 \pm 0.00004$ & 0.001 & 0.007 & 0.0004 \\
\hline 01.05.-31.05.2019 & 744 & $0.003 \pm 0.00004$ & 0.001 & 0.007 & 0.0009 \\
\hline 01.06.-30.06.2017 & 720 & $0.007 \pm 0.00005$ & 0.001 & 0.012 & 0.003 \\
\hline 01.06.-30.06.2018 & 720 & $0.004 \pm 0.00003$ & 0.0009 & 0.007 & 0.001 \\
\hline 01.06.-30.06.2019 & 720 & $0.004 \pm 0.00004$ & 0.001 & 0.008 & 0.0009 \\
\hline 01.07.-31.07.2017 & 741 & $0.008 \pm 0.00005$ & 0.001 & 0.014 & 0.003 \\
\hline 01.07.-31.07.2018 & 741 & $0.004 \pm 0.000003$ & 0.0009 & 0.007 & 0.001 \\
\hline 01.08.-31.08.2017 & 744 & $0.004 \pm 0.00005$ & 0.001 & 0.010 & 0.001 \\
\hline 01.08.-31.08.2018 & 744 & $0.004 \pm 0.00003$ & 0.0009 & 0.006 & 0.0004 \\
\hline 01.09.-30.09.2017 & 720 & $0.003 \pm 0.00003$ & 0.0008 & 0.006 & 0.0007 \\
\hline 01.09.-30.09.2018 & 720 & $0.003 \pm 0.00004$ & 0.001 & 0.01 & 0.0006 \\
\hline 01.10.-31.10.2016 & 85 & $0.005 \pm 0.0001$ & 0.001 & 0.009 & 0.002 \\
\hline $01.10 .-31.10 .2017$ & 744 & $0.005 \pm 0.0006$ & 0.002 & 0.009 & 0.0007 \\
\hline 01.10.-31.10.2018 & 743 & $0.003 \pm 0.00003$ & 0.0009 & 0.006 & 0.0003 \\
\hline 01.11.-30.11.2016 & 720 & $0.004 \pm 0.00004$ & 0.001 & 0.008 & 0.002 \\
\hline $01.11 .-30.11 .2017$ & 720 & $0.004 \pm 0.00004$ & 0.0009 & 0.007 & 0.002 \\
\hline 01.11.-30.11.2018 & 720 & $0.003 \pm 0.00003$ & 0.0008 & 0.005 & 0.0007 \\
\hline 01.12.-31.12.2016 & 744 & $0.004 \pm 0.00004$ & 0.001 & 0.008 & 0.002 \\
\hline $01.12 .-31.12 .2017$ & 744 & $0.004 \pm 0.00004$ & 0.001 & 0.007 & 0.001 \\
\hline 01.12.-31.12.2018 & 744 & $0.003 \pm 0.00003$ & 0.0008 & 0.005 & 0.0004 \\
\hline
\end{tabular}

The bold values indicate the entire measurement period

Low values were recorded between January and March $\left(600-800 \mathrm{~Bq} / \mathrm{m}^{3}\right)$, in the exceptionally cold months of August and September $\left(400-1000 \mathrm{~Bq} / \mathrm{m}^{3}\right)$ and in November and December (about $1100 \mathrm{~Bq} / \mathrm{m}^{3}$ ). The highest mean values, exceeding $2200 \mathrm{~Bq} / \mathrm{m}^{3}$, were recorded in summer 2017 (Figs. 5 and 7, Table 3). The results obtained demonstrate that even in February 2017, where the lowest radon activity concentrations were measured (average $662 \mathrm{~Bq} / \mathrm{m}^{3}$ ), the mean ${ }^{222} \mathrm{Rn}$ activity concentration was more than twice as high as the reference level recommended for workplaces by the European Commission (EU Council Directive 2013). The mean annual ${ }^{222} \mathrm{Rn}$ activity concentration was slightly higher $\left(1179 \mathrm{~Bq} / \mathrm{m}^{3}\right)$ in 2017 and lower $\left(943 \mathrm{~Bq} / \mathrm{m}^{3}\right)$ in 2018 , because of the ongoing construction works (Table 3). 


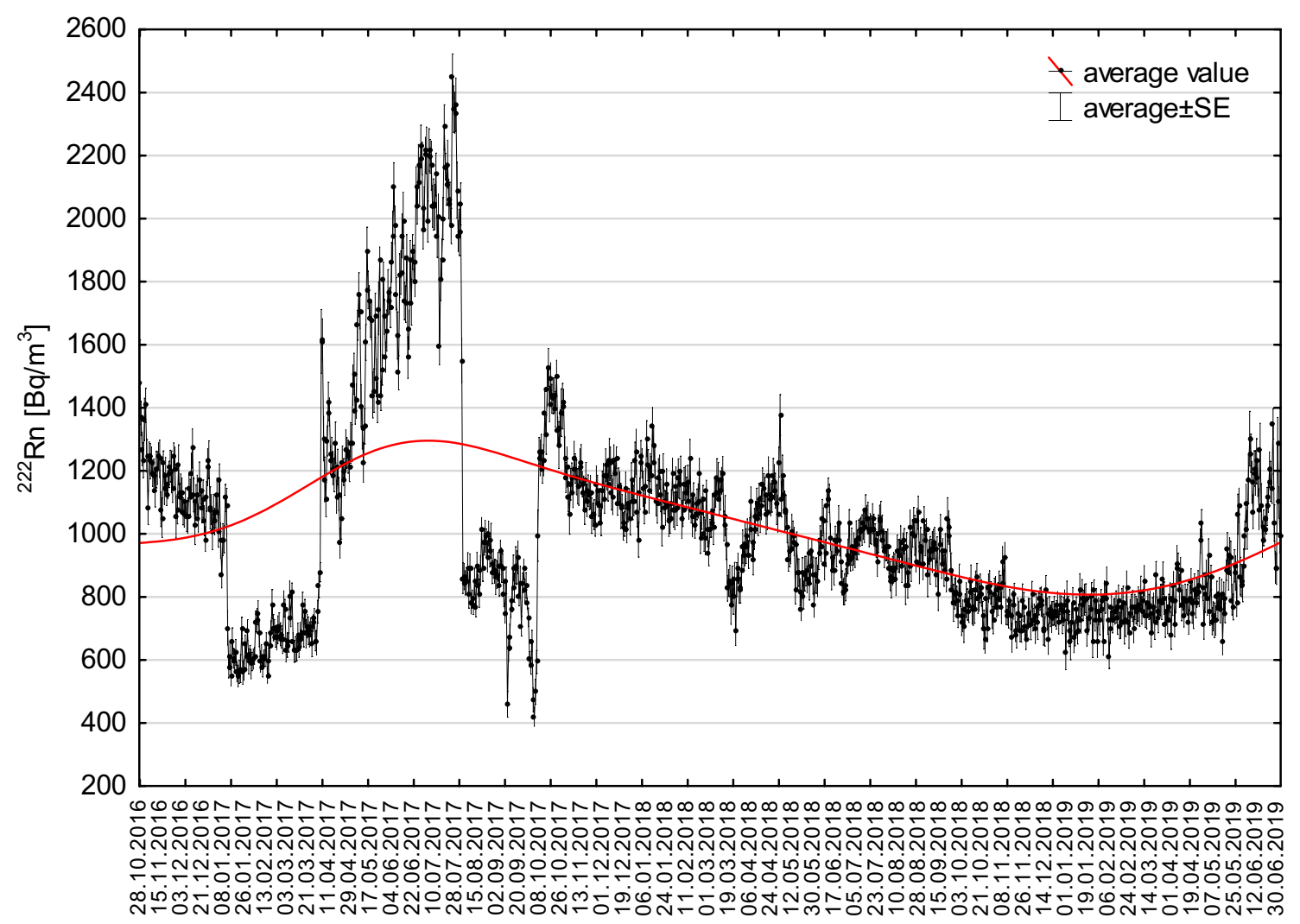

Date

Fig. 4 Radon activity concentrations changes as measured throughout the entire observation period from 28 October 2016 to 2 July 2019 at the measurement location (see Fig. 2) below the forecourt of Książ

\section{Daily changes in ${ }^{222} \mathrm{Rn}$ concentrations}

For the period undisturbed by construction works, hourly changes in ${ }^{222} \mathrm{Rn}$ activity concentration were analyzed by studying 7-day periods in April, July, October and February, representing the four seasons of 2017 (spring, summer, autumn and winter), respectively (Fig. 8). Given the observed fluctuations, no significant daily changes in ${ }^{222} \mathrm{Rn}$ activity concentration can be deduced. In fact, the identified concentrations differed by no more than $10 \%$ from the corresponding mean values (Fig. 8). In February and July, a similar situation was observed. In both cases, there is a rather stable natural ventilation, which is efficient in winter and very inefficient in summer. As a consequence, ${ }^{222} \mathrm{Rn}$ activity concentrations differed only about $100 \mathrm{~Bq} / \mathrm{m}^{3}$ and $200 \mathrm{~Bq} / \mathrm{m}^{3}$ from their mean values of about $700 \mathrm{~Bq} / \mathrm{m}^{3}$ and around $2200 \mathrm{~Bq} / \mathrm{m}^{3}$, respectively (Fig. 8).

In the so-called transitional periods in April and October, the observed daily changes in ${ }^{222} \mathrm{Rn}$ concentrations were characterized by unstable and changing conditions of natural ventilation (Fig. 8). In April, higher values than in the morning and around noon were registered in the afternoon and castle. Red line-moving average value of ${ }^{222} \mathrm{Rn}$ activity concentration. $S E$ standard error

at night (Fig. 8). In October, lower values were recorded until noon (12:00) as compared to the afternoon and at night, where ${ }^{222} \mathrm{Rn}$ activity concentrations increased. The mean values of ${ }^{222} \mathrm{Rn}$ activity concentration were slightly higher in October than in April, with values in the range $1400-1500 \mathrm{~Bq} / \mathrm{m}^{3}$ (Fig. 8). In April, the mean ${ }^{222} \mathrm{Rn}$ activity concentrations fell within the range of 1100-1300 Bq/ $\mathrm{m}^{3}$ (Fig. 8). The results shown in Fig. 8 suggest that only in April and October daily changes in ${ }^{222} \mathrm{Rn}$ concentrations may be relevant for choosing hours of work (including the opening hours for visitors).

\section{Dose assessment}

Since January 2018, workers (mainly tour guides, maintenance workers and researchers) have been spending an average of $8 \mathrm{~h}$ a day inside the facility, including $80 \%$ of the time spent inside the underground workings and the remaining $20 \%$ outside. For individual workers, the work time schedule was established based on the personal interviews with the facility managers and the work time register for the guides (Table 1). 


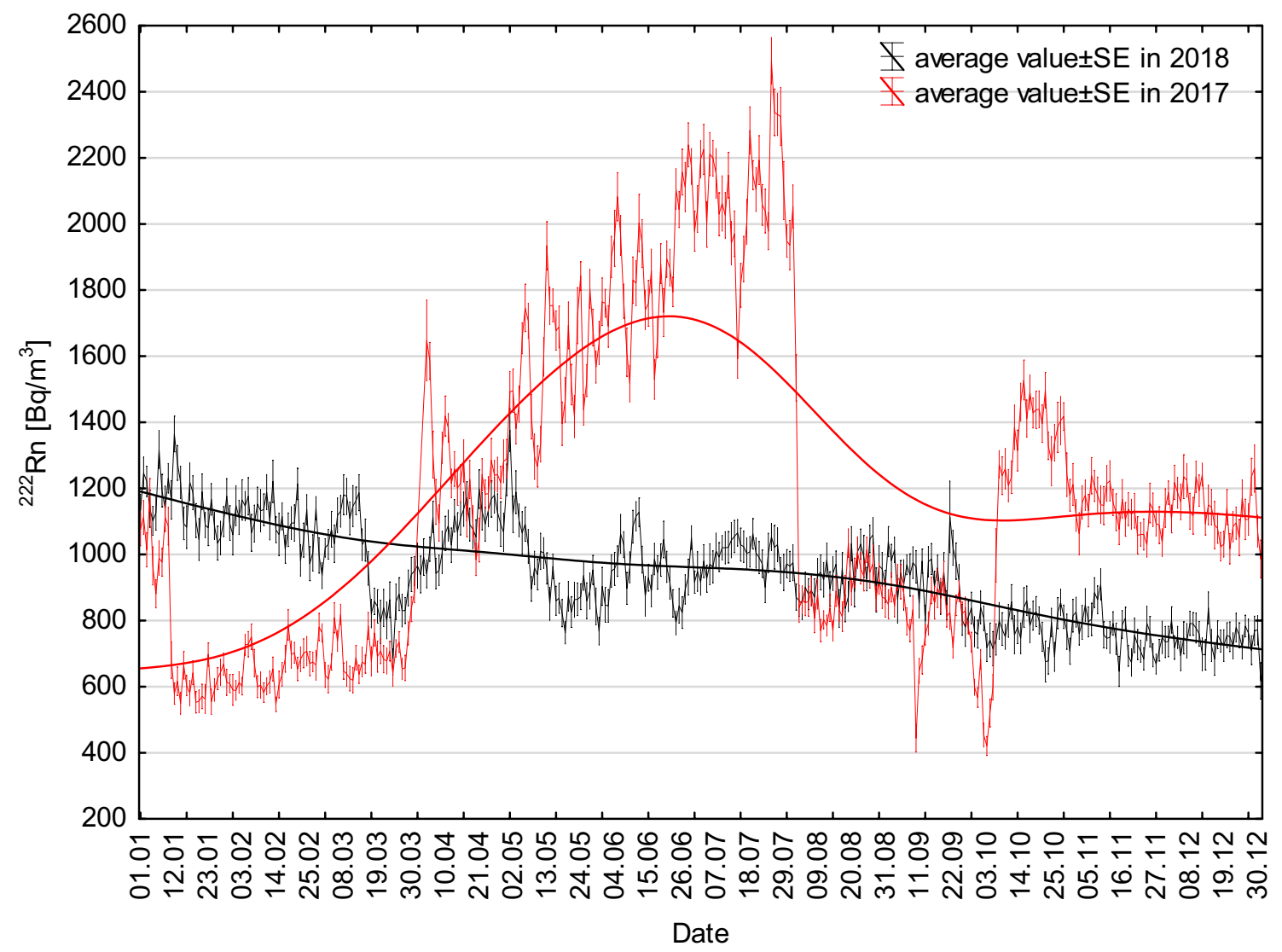

Fig. 5 Radon activity concentration changes recorded below the forecourt of Książ castle throughout the 2 years of observation: from 1 January 2017 to 31 December 2017 and from 1 January 2018 to 31

It was estimated that the lowest average effective dose from ${ }^{222} \mathrm{Rn}$ and its decay products was received by employees in February 2017 and the highest in July 2017. The mean effective dose rates for 2017 and 2018 and for the whole measurement period, were $0.004 \mathrm{mSv} / \mathrm{h}$ (Table 2). The maximum effective dose rate of $0.014 \mathrm{mSv} / \mathrm{h}$ was calculated for July 2017, while the minimum effective dose rate$0.0004 \mathrm{mSv} / \mathrm{h}$ - was calculated for May and August 2018. However, after the recommended installation of a mechanical (forced) ventilation system, the observed changes in radon activity concentrations should be mitigated.

\section{Conclusions}

The present assessment of exposure to ionising radiation due to radon inhalation of workers employed in the underground complex of Książ castle and potential future visitors, was based on continuous radon monitoring, performed before, during and after construction works in the study area. Owing to the measured average annual ${ }^{222} \mathrm{Rn}$ activity concentrations, the corresponding effective doses of the
December 2018. Solid line-moving average value of ${ }^{222} \mathrm{Rn}$ activity concentration. $S E$ standard error

employees (considering working time, exposure duration and radiation exposure) were estimated. It was shown that the average annual ${ }^{222} \mathrm{Rn}$ activity concentration in the air of underground spaces at Książ castle, exceeded the reference level of $300 \mathrm{~Bq} / \mathrm{m}^{3}$ recommended by the European Commission. Specifically, in 2017, this reference level was exceeded almost fourfold, and in 2018 over threefold, reaching $1179 \mathrm{~Bq} / \mathrm{m}^{3}$ and $943 \mathrm{~Bq} / \mathrm{m}^{3}$, respectively. In the whole almost 3-year-long research period, the mean radon concentration was $1,025 \mathrm{~Bq} / \mathrm{m}^{3}$. The highest radon concentrations were recorded in the spring and summer months, i.e., from April to July. In July 2017, a maximum radon concentration of $3629 \mathrm{~Bq} / \mathrm{m}^{3}$ was recorded. It should be emphasized that opening (in 2018) new staircases for tourists in shafts and opening a ventilation window in one of the adits have improved the ventilation in the studied underground area. As a result, ${ }^{222} \mathrm{Rn}$ activity concentrations decreased, but are still higher than the recommended reference level of $300 \mathrm{~Bq} / \mathrm{m}^{3}$.

In the period undisturbed by construction works, ${ }^{222} \mathrm{Rn}$ activity concentrations showed some seasonal variations characteristic of underground spaces well isolated from the atmosphere. After launching the adaptation work in August 


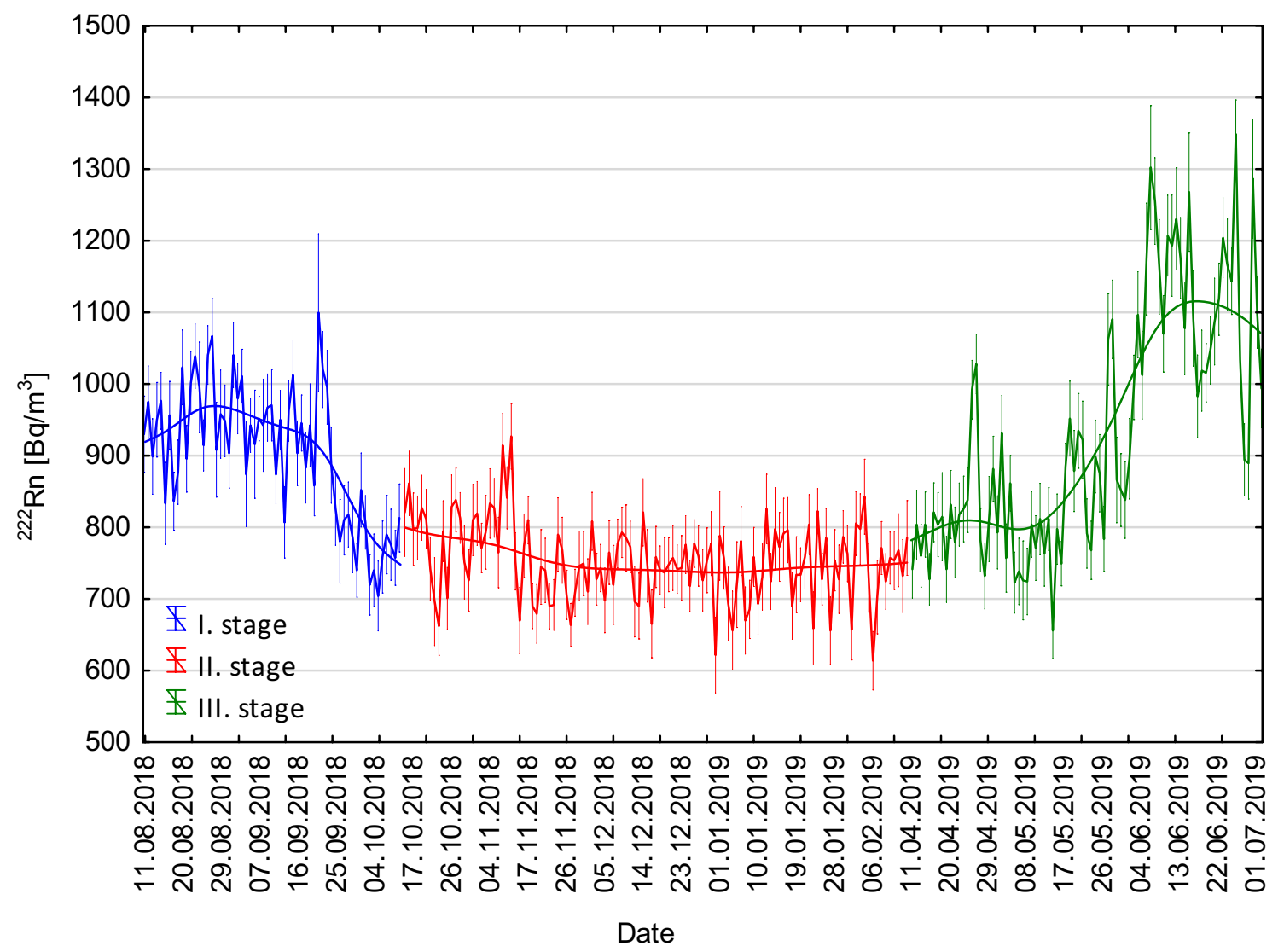

Fig. 6 Courses of changes in ${ }^{222} \mathrm{Rn}$ activity concentration registered at successive stages of the facility creation: stage 1-adaptation works from 11 August 2018 to 10 October 2018, stage 2-opening of the tourist route from 15 October 2018 to 10 April 2019, stage 3-

2018 , the character of the observed changes in ${ }^{222} \mathrm{Rn}$ activity concentration was influenced by the forced ventilation conditions in the workings, i.e., the size of the flowing air stream and the direction of its circulation. As a result, the level of ${ }^{222} \mathrm{Rn}$ activity concentration measured in the warmer season (May-September) was similar or slightly lower than that in autumn and winter. The direction of air flow, mainly in the summer, indicated circulation from the north-west to the south. The air was released from the working areas to the atmosphere through a ventilation window located in adit no. 4 , about $15 \mathrm{~m}$ below the level of the staircase. In winter, air exchange occurred in the opposite direction. The ventilation conditions in the facility affected the distribution of daily changes in ${ }^{222} \mathrm{Rn}$ activity concentration only in the so-called transitional periods (April-October), where they were also undisturbed by construction work. Relevant and predictable daily changes in radon concentration occurred in no more than about a dozen days a year-a few days in spring and a few in autumn. Because of this and because significant differences did not exceed $10 \%$ from the corresponding mean values, daily changes in ${ }^{222} \mathrm{Rn}$ activity concentration are not facility operation and monitoring of the ionising radiation exposure conditions from 11 April 2019 to 02 July 2019. Solid line-moving average value of ${ }^{222} \mathrm{Rn}$ activity concentration. Mean \pm SE; SE standard error

considered important in the planning of working time under the ground.

The estimated average effective dose rates (effective dose per $1 \mathrm{~h}$ of work in the underground spaces under Książ castle) varied from 0.003 to $0.005 \mathrm{mSv} / \mathrm{h}$. In general, for members of the public the mean annual effective dose should not significantly exceed $1 \mathrm{mSv} / \mathrm{year}$. The present study showed that members of the general public, chiefly tourists, but also underage persons like pupils or apprentices spending no more than $1 \mathrm{~h}$ a day once a year in the studied facility (note that the duration of a touristic tour is about $40 \mathrm{~min}$ ), will not receive an effective dose higher than $1 \mathrm{mSv} /$ year. For a worker, the annual effective dose could reach, at worst, $7.8 \mathrm{mSv}$ within a year. Although this value is lower than the limit of effective dose for employees ( $20 \mathrm{mSv} / \mathrm{year}$ ), it means that in the present conditions, the employees could be exposed to ionising radiation exceeding $6 \mathrm{mSv} /$ year and $1 \mathrm{mSv} /$ year at best. However, it must be noted that the measurement location was selected in such a way that the ${ }^{222} \mathrm{Rn}$ activity concentration measured was highest for the whole underground complex. Based on the results obtained, it is 


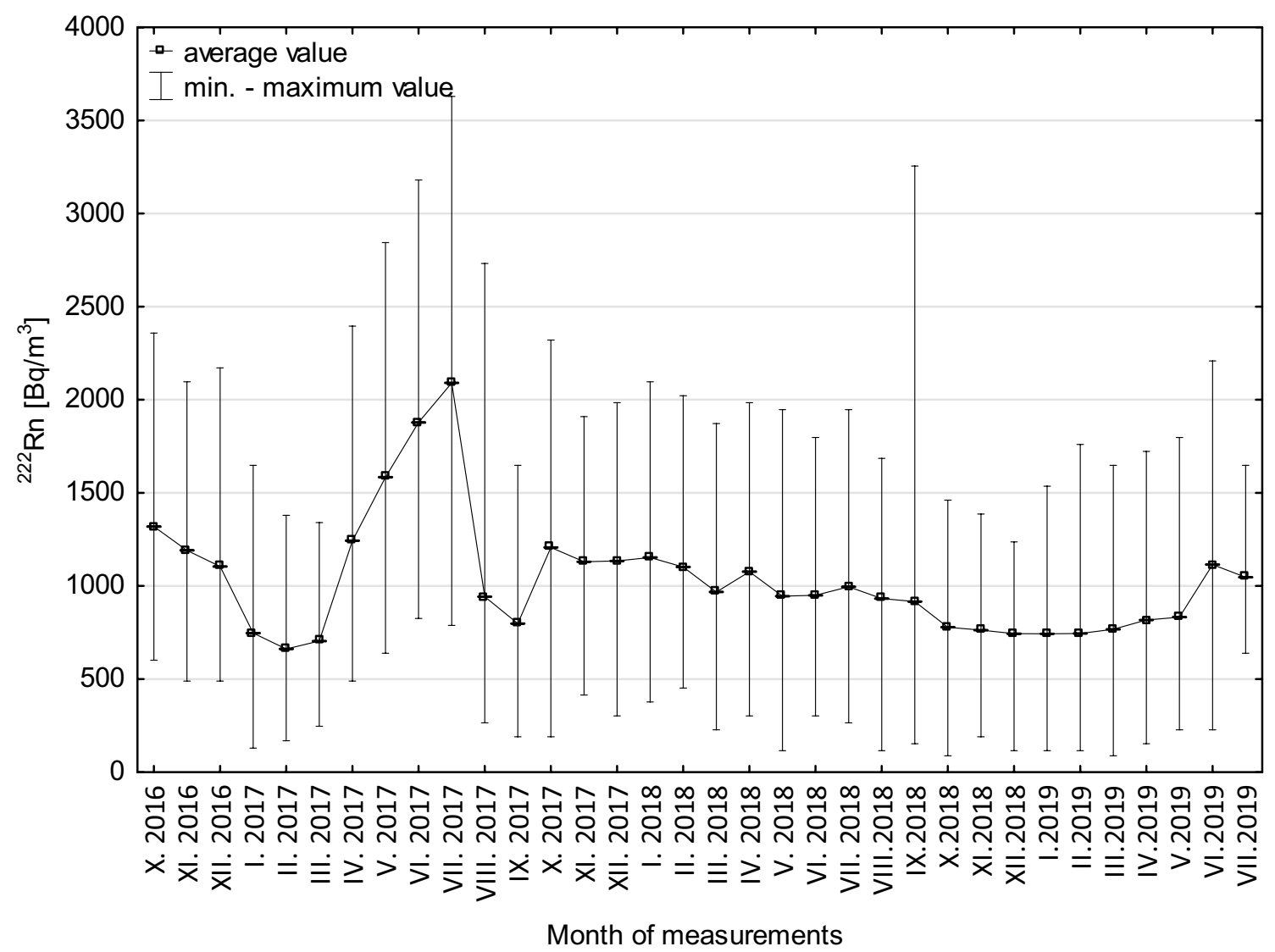

Fig. 7 Box-and-whisker plot of measured ${ }^{222}$ Rn activity concentrations registered in a particular month between 28 October 2016 and 2 July 2019

recommended to base environmental dosimetry in the studied underground facility on radon concentration monitoring. Of course, routine radon monitoring should be based on the measurements at several locations along the tourist route. To select the best method (individual or environmental) of monitoring, the expected effective dose and time of exposure should be taken into account.

The occupational exposure to ionising radiation from radon and its progeny in the underground tourist route at Książ castle is a vital problem and it requires a solution compliant with the Polish regulations of the amended Atomic Law and guidelines appended to this law (Law 2000, Item 1792 with appendices). One method of improving working conditions there is increasing the effectiveness of ventilation in working areas. The whole tourist route should be supplied with atmospheric air, not only during time periods with limited natural air exchange (mostly during the transitional periods), but also during the so-called tourist season in summer, when many tourists and service personnel are present. One proposed way is the application of a natural longitudinal ventilation system with fans (Fig. 3b). In such a system, air circulation is triggered by overpressure generated by fans placed near the entrance portal (in adit no. 2) or near the exit of the facility (in adit no. 3). Also worth considering is the installation of a radon monitoring system, which would provide continuous (online) information on the radiation situation along the tourist route. Such a system should include detectors installed at several (3-5) measurement locations. Furthermore, it is necessary to record the working time (exposure time) of any workers in the underground.

The results of the present study demonstrate the importance of radon monitoring in underground facilities, as a model of good practice for radiological protection of workers. Such kind of monitoring should be made mandatory by international and national authorities, for all facilities in similar locations in Poland and worldwide. 
Table $3{ }^{222} \mathrm{Rn}$ activity concentrations recorded throughout the observation period between 28 October 2016 and 2 July 2019 in the working areas of the underground tourist route at Książ castle

\begin{tabular}{|c|c|c|c|c|c|c|c|}
\hline Measurement period & $\begin{array}{l}\text { Number of hourly } \\
\text { measurements }\end{array}$ & Average $\left(\mathrm{Bq} / \mathrm{m}^{3}\right)$ & $\operatorname{Median}\left(\mathrm{Bq} / \mathrm{m}^{3}\right)$ & $\begin{array}{l}\text { Minimum } \\
\left(\mathrm{Bq} / \mathrm{m}^{3}\right)\end{array}$ & $\begin{array}{l}\text { Maximum } \\
\left(\mathrm{Bq} / \mathrm{m}^{3}\right)\end{array}$ & $\begin{array}{l}\text { Standard devia- } \\
\text { tion }\left(\mathrm{Bq} / \mathrm{m}^{3}\right)\end{array}$ & $\begin{array}{l}\text { Standard } \\
\text { error }(\mathrm{Bq} / \\
\left.\mathrm{m}^{3}\right)\end{array}$ \\
\hline 01.01.-31.12.2017 & 8675 & 1179 & 1087 & 130 & 3629 & 538 & 5.8 \\
\hline 01.01.-31.12.2018 & 8754 & 943 & 938 & 88 & 3255 & 280 & 3.0 \\
\hline 28.10.2016-02.07.2019 & 23,370 & 1025 & 938 & 88 & 3629 & 419 & 2.7 \\
\hline 01.01.-31.01.2017 & 744 & 747 & 714 & 130 & 1648 & 292 & 10.7 \\
\hline 01.01.-31.01.2018 & 744 & 1153 & 1125 & 377 & 2096 & 264 & 9.7 \\
\hline 01.01.-31.01.2019 & 744 & 743 & 751 & 116 & 1536 & 228 & 8.3 \\
\hline 01.02.-28.02.2017 & 672 & 662 & 637 & 169 & 1379 & 185 & 7.1 \\
\hline 01.02.-28.02.2018 & 672 & 1102 & 1087 & 452 & 2021 & 259 & 10.0 \\
\hline 01.02.-28.02.2019 & 672 & 745 & 751 & 116 & 1760 & 232 & 9.0 \\
\hline 01.03.-31.03.2017 & 744 & 704 & 676 & 247 & 1340 & 186 & 6.8 \\
\hline 01.03.-31.03.2018 & 744 & 968 & 975 & 228 & 1872 & 280 & 10.3 \\
\hline 01.03.-31.03.2019 & 744 & 767 & 751 & 88 & 1648 & 226 & 8.3 \\
\hline 01.04.-30.04.2017 & 638 & 1243 & 1237 & 489 & 2395 & 301 & 11.9 \\
\hline 01.04.-30.04.2018 & 718 & 1077 & 1087 & 302 & 1984 & 267 & 10.0 \\
\hline 01.04.-30.04.2019 & 720 & 817 & 788 & 153 & 1723 & 234 & 8.7 \\
\hline $01.05 .-31.05 .2017$ & 744 & 1584 & 1573 & 639 & 2844 & 338 & 12.4 \\
\hline $01.05 .-31.05 .2018$ & 744 & 945 & 938 & 116 & 1947 & 270 & 9.9 \\
\hline 01.05.-31.05.2019 & 744 & 833 & 826 & 228 & 1797 & 254 & 9.3 \\
\hline 01.06.-30.06.2017 & 720 & 1878 & 1872 & 826 & 3180 & 359 & 13.4 \\
\hline 01.06.-30.06.2018 & 720 & 950 & 938 & 302 & 1797 & 244 & 9.1 \\
\hline 01.06.-30.06.2019 & 720 & 1115 & 1087 & 228 & 2209 & 318 & 11.8 \\
\hline 01.07.-31.07.2017 & 741 & 2091 & 2059 & 788 & 3629 & 369 & 13.6 \\
\hline 01.07.-31.07.2018 & 741 & 996 & 975 & 265 & 1947 & 236 & 8.7 \\
\hline 01.08.-31.08.2017 & 744 & 942 & 863 & 265 & 2732 & 324 & 11.9 \\
\hline 01.08.-31.08.2018 & 744 & 932 & 938 & 116 & 1685 & 247 & 9.0 \\
\hline 01.09.-20.09.2017 & 720 & 798 & 788 & 190 & 1648 & 221 & 8.3 \\
\hline 01.09.-30.09.2018 & 720 & 917 & 900 & 153 & 3255 & 267 & 10.0 \\
\hline 28.10.-31.10.2016 & 85 & 1319 & 1349 & 601 & 2358 & 314 & 34.1 \\
\hline 01.10.-31.10.2017 & 744 & 1207 & 1274 & 190 & 2321 & 415 & 15.2 \\
\hline 01.10.-31.10.2018 & 743 & 779 & 751 & 88 & 1461 & 234 & 8.6 \\
\hline 01.11.-30.11.2016 & 720 & 1191 & 1199 & 489 & 2096 & 266 & 9.9 \\
\hline 01.11.-30.11.2017 & 720 & 1130 & 1125 & 415 & 1910 & 251 & 9.4 \\
\hline 01.11.-30.11.2018 & 720 & 763 & 751 & 190 & 1386 & 213 & 7.9 \\
\hline 01.12.-31.12.2016 & 744 & 1105 & 1106 & 489 & 2171 & 259 & 9.5 \\
\hline $01.12 .-31.12 .2017$ & 744 & 1134 & 1125 & 302 & 1984 & 259 & 9.5 \\
\hline 01.12.-31.12.2018 & 744 & 744 & 751 & 116 & 1237 & 210 & 7.7 \\
\hline
\end{tabular}

The bold values indicate the entire measurement period 
Fig. 8 Courses of hourly changes in ${ }^{222} \mathrm{Rn}$ activity concentration registered on 7 consecutive days in winter (13-20 February 2017), in spring (13-20 April 2017), in summer (13-20 July 2017) and in autumn (13-20 October 2017), during a period undisturbed by construction works. Solid lines: moving average fit; $\mathrm{R}$-right $y$ axis; L-left $y$ axis; E mean $\pm \mathrm{SE} ; S E$ standard error

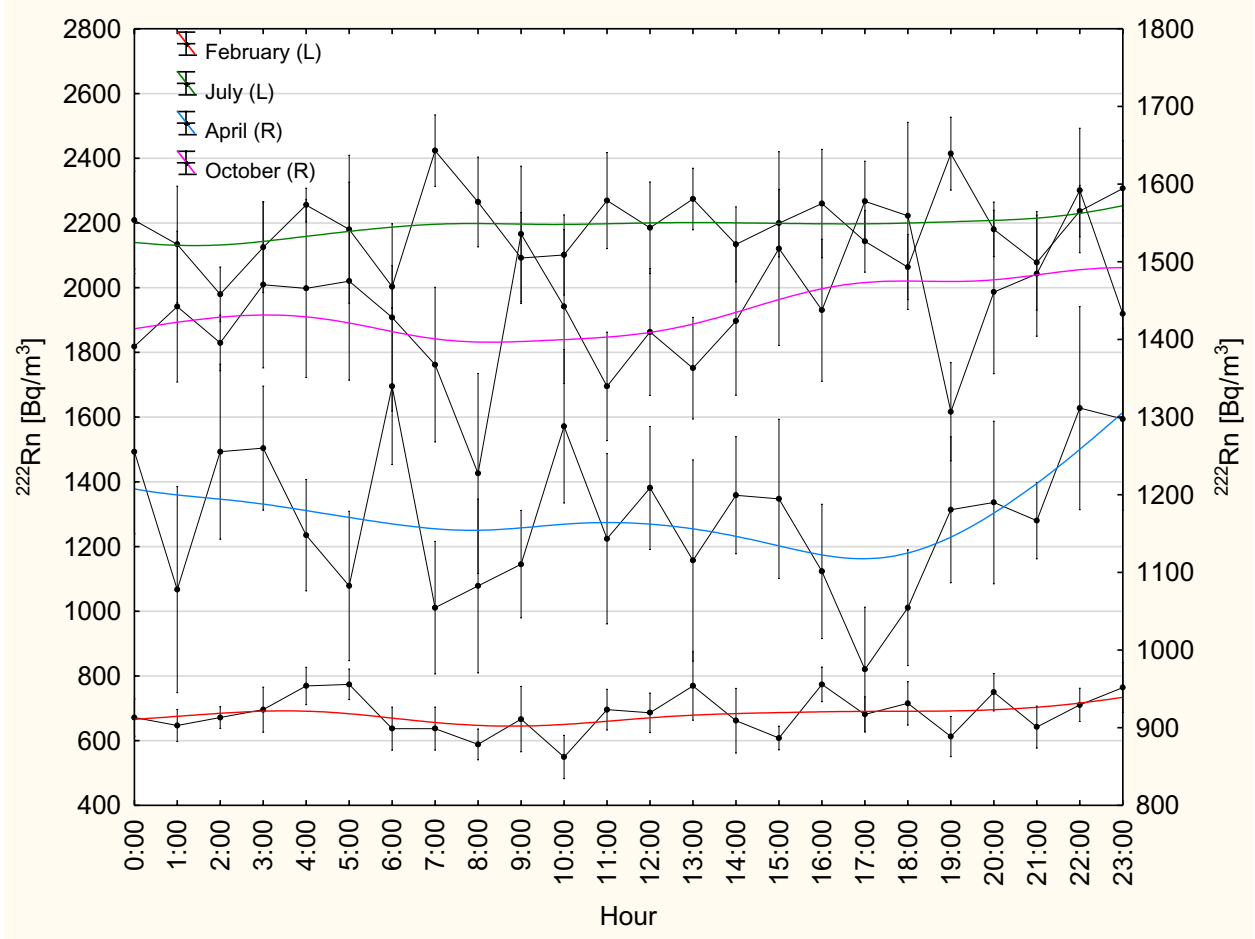

Acknowledgements The research was carried out as a series of projects no.: 4002/0082/16, 4002/0018/17/1, 4002/0007/18/3 and $4002 / 0006 / 19 / 2$ carried out at the Faculty of Civil Engineering and the Faculty of Geoengineering, Mining and Geology, Wrocław University of Science and Technology. The projects were financed as commissions by the partnership Zamek Książ w Wałbrzychu Sp. z o.o. The authors received written permission from the ordering party to publish the research results. The authors extend special thanks to Mr. Bogdan Rosicki, representing the management Książ Castle for their time and help during measurements.

Author contributions The authors wrote the manuscript and analyzed the data. Lidia Fijałkowska-Lichwa collected the data. The authors reviewed the results and provided guidelines for presentation and interpretation. All authors read and approved the final manuscript.

Data availability All relevant data and materials are presented in the paper.

\section{Declarations}

Conflict of interest The authors state that there are no conflicts of interest regarding the publication of this article and that there are no financial ties to disclose.

Informed consent Consent for publication was obtained.

Open Access This article is licensed under a Creative Commons Attribution 4.0 International License, which permits use, sharing, adaptation, distribution and reproduction in any medium or format, as long as you give appropriate credit to the original author(s) and the source, provide a link to the Creative Commons licence, and indicate if changes were made. The images or other third party material in this article are included in the article's Creative Commons licence, unless indicated otherwise in a credit line to the material. If material is not included in the article's Creative Commons licence and your intended use is not permitted by statutory regulation or exceeds the permitted use, you will need to obtain permission directly from the copyright holder. To view a copy of this licence, visit http://creativecommons.org/licenses/by/4.0/.

\section{References}

Abdelzaher M (2011) Seasonal variation of radon level and radon effective doses in the Catacomb of Kom EI-Shuqafa, Alexandria, Egypt. Pramana J Phys 77(4):749-757. https://doi.org/10.1007/ s12043-011-0150-Z

Alvarez-Gallego M, Garcia-Anton E, Fernandez-Cortes A, Cuezva S, Sanchez-Moral S (2015) High radon levels in subterranean environments: monitoring and technical criteria to ensure human safety (case of Castaňar cave. Spain). J Environ Radioact 145:19-29

Ambrosino F, Thinová L, Briestenský M, Sabbarese C (2019) Analysis of radon time series recorded in Slovak and Czech caves for the detection of anomalies due to seismic phenomena. Radiat Prot Dosim 186(2-3):428-432

Ambrosino F, Thinová L, Briestenský M, Sabbarese C (2020a) Study of ${ }^{222} \mathrm{Rn}$ continuous monitoring time series and dose assessment in six European caves. Radiat Prot Dosim 191(2):233-237

Ambrosino F, Thinová L, Briestenský M, Šebela S, Sabbarese C (2020b) Detecting time series anomalies using hybrid methods applied to radon signals recorded in caves for possible correlation with earthquakes. Acta Geod Geophys 55(3):405-420

Bekteshi S, Kabashi S, Ahmetaj S, Xhaf B, Hodolli G, Kadiri S, Alijaj F, Abdullahu B (2017) Radon concentrations and exposure levels 
in the Trepça underground mine: a comparative study. J Clean Prod 155:198-203

Chao ChYH, Tung TCW, Burnett J (1997) Influence of ventilation on indoor radon level. Build Environ 32(6):527-534

Chibowski S, Komosa A (2001) Radon concentration in basements of old town buildings in the Lublin region, Poland. J Radioanal Nucl Chem 247(1):53-56

Cucoş Dinu A, Călugăr M, Burghele BD, Dumitru OA, Cosma C, Onac BP (2017) Radon levels in Romanian caves: an occupational exposure survey. Environ Geochem Health 39(5):1085-1099. https:// doi.org/10.1007/S10653-016-9878-1

Da Silva AAR, Valladares DL, Anjos RM, Velasco H, Rizzotto M, Yoshimura EM (2011) Assessment the health hazard from ${ }^{222} \mathrm{Rn}$ in old metalliferous mines in San Luis, Argentina. Water Air Soil Pollut 218:371-386. https://doi.org/10.1007/S11270-010-0652-1

Dueñas C, Fernández MC, Cañete S, Pérez M, Gordo E (2011) Seasonal variations of radon and the radiation exposure levels in Nerja cave, Spain. Radiat Meas 46:1181-1186

Dumitru OA, Onac BP, Fornős JJ, Cosma C (2015a) Radon concentration and effective dose assessment in Coves De Campanet (Mallorca Island, Spain). J Radioanal Nucl Chem 303:885-890. https:// doi.org/10.1007/S10967-014-3511-5

Dumitru OA, Onac BP, Fornős JJ, Cosma C, Ginés A, Ginés J, Merino A (2015b) Radon survey in caves from Mallorca Island, Spain. Sci Total Environ 526:196-203

Dumitru OA, Onac BP, Cosma C (2016) Radon levels in caves from San Salvador, the Bahamas: a reconnaissance survey. Carbonates Evaporites 31:153-161. https://doi.org/10.1007/ S13146-015-0251-8

Espinosa G, Golzarri JI, Vega-Orihuela E, Morales-Malacara JB (2013) Indoor radon concentration levels in Mexican caves using nuclear track methodology and the relationship with living habits of the bats. J Radioanal Nucl Chem 296:43-48. https://doi.org/10.1007/S10967-012-1975-8

EU Council Directive 2013/59/EURATOM of 5 December 2013 laying down basic safety standards for protection against the dangers arising from exposure to ionising radiation and repealing. Directives 89/618/Euratom, 90/641/Euratom, 96/29/Euratom, 97/43/Euratom and 2003/122/Euratom. Off J Eur Union. 17.1.2014, L 13/1-L 13/73

Fijałkowska-Lichwa L (2014) Short-term radon activity concentration changes along the underground educational tourist route in the old uranium mine in Kletno (Sudety Mts, SW Poland). J Environ Radioact 135:25-35

Fijałkowska-Lichwa L (2016) Extremely high radon activity concentration in two adits of the abandoned uranium mine 'Podgórze' in Kowary (Sudety Mts, Poland). J Environ Radioact 165:13-23

Fijałkowska-Lichwa L (2020) The assessment of lining structure impact on radon behaviour inside selected underground workings under the cour d'honneur of Książ castle. J Radioanal Nucl Chem 326:1199-1211. https://doi.org/10.1007/ s10967-020-07391-3

Fijałkowska-Lichwa L, Przylibski TA (2011) Short-term ${ }^{222}$ Rn activity concentration changes in underground spaces with limited air exchange with the atmosphere. Nat Hazards Earth Syst Sci 11:1179-1188

Fijałkowska-Lichwa L, Przylibski TA (2016) First radon measurements and occupational exposure assessments in underground geodynamic laboratory the Polish academy of sciences. J Environ Radioact 165:253-269

Fijałkowska-Lichwa L, Przylibski TA (2020) A comprehensive characteristic of ${ }^{222} \mathrm{Rn}$ activity concentration changes and ionising radiation exposure in newly discovered parts of Bear Cave in Kletno, Poland. Radiat Prot Dosim 188(1):79-97. https://doi. org/10.1093/Rpd/Ncz263
Font L, Baixeras C, Moreno V (2008) Indoor radon levels in underground workplaces of Catalonia, Spain. Radiat Meas 43:S467-S470

Gillmore GK, Phillips PS, Denman AR, Gilbertson DD (2002) Radon in the Creswell Crags Permian limestone caves. J Environ Radioact 62:165-179

Gillmore G, Gilbertson D, Grattan J, Hunt Ch, Mclaren S, Pyatt B, Mani Banda R, Barker G, Denman A, Phillips P, Reynolds T (2005) The potential risk from ${ }^{222}$ radon posed to archaeologists and earth scientists: reconnaissance study of radon concentrations, excavations, and archaeological shelters in the Great Cave of Niah, Sarawak, Malaysia. Ecotoxicol Environ Saf 60:213-227

Gruber E, Salama E, Rühm W (2011) Real-time measurement of individual occupational radon exposures in tombs of the Valley of the Kings, Egypt. Radiat Prot Dosim 144(1-4):620-626

Hafez AF, Hussein AS (2001) Radon activity concentrations and effective doses in ancient Egyptian tombs of the Valley of the Kings. Appl Radiat Isot 55:355-362

Hafez AF, Bishara AA, Kotb MA, Hussein AS (2003) Regular radon activity concentration and effective dose measurements inside the great pyramid with passive nuclear track detectors. Health Phys 85(2):210-215

IAEA-International Atomic Energy Agency (1996) International basic safety standards for protection against ionizing radiation and for the safety of radiation sources. Safety series no. 115, Vienna

IAEA-International Atomic Energy Agency (2003) Radiation protection against radon in workplaces other than mines. Safety reports series no. 33, Vienna

IAEA-International Atomic Energy Agency (2014) Radiation protection and safety of radiation sources: international basic safety standards. General safety requirements Part 3, no. GSR Part 3, Vienna

ICRP-International Commission On Radiation Protection (1993) Protection against radon-222 at home and at work. Publication no. 65, Pergamon Press, Oxford

ICRP-International Commission on Radiation Protection (1996) Radiological protection and safety in medicine. ICRP Publication 73. Ann. ICRP 26(2)

ICRP-International Commission on Radiation Protection (2011) Lung cancer risk from radon and progeny. ICRP Publication 115. Ann

ICRP-International Commission on Radiation Protection (2014) Radiological protection against radon exposure. ICRP Publication 126. Ann. ICRP 43(3)

ICRP-International Commission on Radiation Protection (2017) Occupational intakes of radionuclides: Part 3 , vol 46 , no. $3 / 4$ ICRP Publication 137

Kaczorowski M (1999a) The long water-tube clinometer in Książ geophysical station. Promotion of the works. Artif Satell 34(3):171-191

Kaczorowski M (1999b) The results of preliminary tilt measurements by use of the long water-tube clinometer in Książ geophysical station. Artif Satell 34(3):193-201

Kaczorowski M (2009) Discussion on strong non-tidal signals registered by horizontal pendulums and water tube tiltmeters in geodynamic laboratory of PAS in Książ. Acta Geodyn Geomater 6(3):155, 369-381

Kaczorowski M, Wojewoda J (2011) Neotectonic activity interpreted from a long water-tube tiltmeter record at the SRC geodynamic laboratory in Książ, Central Sudetes, SW Poland. Acta Geodyn Geomater 8(3):163, 249-261

Kaczorowski M, Olszak T, Walo J, Barlik M (2012) Research of absolute gravity variations on geodynamic laboratory in Książ in the period 2007-2011. Artif Satell 47(4):169-176 
Kaczorowski M, Kasza D, Zdunek R, Wronowski R (2018) Application of observations of recent tectonic activity in the Świebodzice depression (The Sudetes, SW Poland) in assessing seismic hazard in the Fore-Sudetic Monocline. In: Blachowski J, Górniak-Zimroz J, Kasza D (eds) XXIII autumn school of geodesy. September 21-22, 2017. Wałbrzych, Poland

Kalarus J (2001) The underground Książ. Cryptonym Riese, Nowa Ruda (in Polish)

Kasza D, Kaczorowski M, Zdunek R, Wronowski R (2014) The damages of Książ castle architecture in relation to routes of recognized tectonic faults and indications of recent tectonic activity of Świebodzice Depression Orogen-Central Sudetes, SW Poland. Acta Geodyn Geomater 11(3):175, 225-234

Kasza D, Kowalski A, Wojewoda J, Kaczorowski M (2018) Indicators of recent Geodynamic Activity in the Książ castle area (Świebodzice Unit, Sudetes) in the light of structural analysis and geodetic measurements. In: Przylibski TA, Kasza D (eds) XVII conference of Ph.d. students and young scientists, E3S Web Of Conferences, vol 29. https://doi.org/10.1051/E3sconf/20182 900021 (in Polish)

Korhonen P, Kokotti H, Kalliokoski P (2000) Survey and mitigation of occupational exposure of radon in workplaces. Build Environ 35:555-562

Kruszyński P (2004) Underground structures in the Owl mountains and Książ castle, Wałbrzych (in Polish)

Lamparska J (1998) Mysteries. Castles. Underground systems. A guidebook you have never seen, Wrocław (in Polish)

Lario J, Sánchez-Moral S, Cuezva S, Taborda M, Soler V (2006) High ${ }^{222} \mathrm{Rn}$ levels in a show cave (Castañar De Ibor, Spain): proposal and application of management measures to minimize the effects on guides and visitors. Atmos Environ 40:7395-7400

Law of 29 November 2000 R. Atomic Law-Dz. U. 2019 Poz. 1792 (in Polish)

Liu C, Zeng Z, Ma H, Cheng J, Li J, Zhang H (2018) The CR-39 etching optimization and measurement for radon in China Jinping underground laboratory. J Radioanal Nucl Chem 318:1369-1377. https://doi.org/10.1007/S10967-018-6201-X

Martinez T, Martinez G, Juarez F, Navarrete M, Espinosa G, Golzarri JI, Cabrera L, Gonzalez P (2005) Indoor radon and thoron concentrations in the pyramides of Teotihuacan. J Radioanal Nucl Chem 264(2):511-516

Nawrat S, Napieraj S (2005) Ventilation and safety in transportation tunnels. Uczelniane Wydawnictwa Naukowo-Techniczne. AGH, Kraków (in Polish)

Nawrat S, Napieraj S, Schmidt N (2012) Ventilation of transportation tunnels during the tunneling process. Budownictwo Górnicze i Tunelowe. Kwartalnik Naukowo-Techniczny 2:55-63 (in Polish)

Olszewski J, Chruścielewski W, Jankowski J (2005) Radon on underground tourist routes in Poland. International Congress Series 1276. Elsevier, pp 360-361

Olszewski J, Zmyślony M, Wrzesień M, Walczak K (2015) Occurrence of radon in Polish underground tourist routes. Med Pr 66(4):557563 (in Polish)

Özen AS, Çevik U, Taşkin H (2019) Comparison of active and passive radon survey in cave atmosphere and estimation of the radon exposed dose equivalents and gamma absorbed dose rates. Isot Environ Health Stud 55(1):92-109. https://doi.org/10.1080/10256 016.2018 .1557163

Pawlikowska M (2008) Książ castle-mysteries of the past as a chance to revive tourist attendance. In: Dziedzictwo Kulturowe-Ochrona i adaptacja jako szansa na rozwój. Koło Naukowe Młodych Geografów "Geoholicy", Uniwersytet Łódzki (in Polish)

Perrier F, Richon P, Gautam U, Tiwari DR, Shrestha P, Sapkota SN (2007) Seasonal variations of natural ventilation and radon-222 exhalation in a slightly rising dead-end tunnel. J Environ Radioact 97:220-235

Porębski SJ (1981) Świebodzice succession (Upper Devonian-Lower Carboniferous. Western Sudetes): a prograding mass-flow dominated fan-delta complex. Geol Sudet 16(1):99-190

Przylibski TA (1996) Variation in radon concentration in the air of Bear Cave in Kletno (the Sudetes). Prz Geol 44(9):942-944 (in Polish)

Przylibski TA (1999) Radon concentration changes in the air of two caves in Poland. J Environ Radioact 45:81-94

Przylibski TA (2001) Radon and its daughter products behaviour in the air of an underground tourist route in the former arsenic and gold mine in Złoty Stok (Sudety Mountains, SW Poland). J Environ Radioact 57:87-103

Przylibski TA (2004) Concentration of ${ }^{226} \mathrm{Ra}$ in rocks of the southern part of Lower Silesia (SW Poland). J Environ Radioact 75(2):171-191

Przylibski TA (2015) Radon research in Poland: a review. Solid State Phenom 238:90-115

Przylibski TA (2018) Radon: a radioactive therapeutic element. In: Gillmore GK, Perrier FE, Crockett RGM (eds) Radon, health and natural hazards, vol 451. Geological Society, London, pp 209 236. https://doi.org/10.1144/SP451.7

Przylibski TA, Ciężkowski W (1999) Seasonal changes in radon concentration in Niedźwiedzia Cave (SW Poland). Il Nuovo Cimento 22C(3-4):463-469

Przylibski TA, Fijałkowska-Lichwa L (2017a) Research of ${ }^{222}$ Rn activity concentrations in the air of underground workings of the planned tourist route at Książ. Part 2. Raporty Wydziału Geoinżynierii, Górnictwa i Geologii Politechniki Wrocławskiej Ser. SPR 9, 27 (in Polish)

Przylibski TA, Fijałkowska-Lichwa L (2017b) Research of ${ }^{222} \mathrm{Rn}$ activity concentrations in the air of underground workings of the planned tourist route at Książ. Part 3. Raporty Wydziału Geoinżynierii, Górnictwa i Geologii Politechniki Wrocławskiej Ser. SPR 20, 26 (in Polish)

Przylibski TA, Fijałkowska-Lichwa L (2018a) Research of ${ }^{222} \mathrm{Rn}$ activity concentrations in the air of underground workings of the planned tourist route at Książ. Part 4. Raporty Wydziału Geoinżynierii, Górnictwa i Geologii Politechniki Wrocławskiej Ser. SPR 1, 26 (in Polish)

Przylibski TA, Fijałkowska-Lichwa L (2018b) Research of ${ }^{222} \mathrm{Rn}$ activity concentrations in the air of underground workings of the planned tourist route at Książ. Part 5. Raporty Wydziału Geoinżynierii, Górnictwa i Geologii Politechniki Wrocławskiej Ser. SPR 15, 27 (in Polish)

Przylibski TA, Fijałkowska-Lichwa L (2018c) Research of ${ }^{222}$ Rn activity concentrations in the air of underground workings of the planned tourist route at Książ. Part 6. Raporty Wydziału Geoinżynierii, Górnictwa i Geologii Politechniki Wrocławskiej Ser. SPR 23, 30 (in Polish)

Przylibski TA, Fijałkowska-Lichwa L (2018d) Research of ${ }^{222} \mathrm{Rn}$ activity concentrations in the air of underground workings of the planned tourist route at Książ. Part 7. Raporty Wydziału Geoinżynierii, Górnictwa i Geologii Politechniki Wrocławskiej Ser. SPR 31, 30 (in Polish)

Przylibski TA, Fijałkowska-Lichwa L (2019) Research of ${ }^{222} \mathrm{Rn}$ activity concentrations in the air of underground workings of the planned tourist route at Książ. Part 8. Raporty Wydziału Geoinżynierii, Górnictwa i Geologii Politechniki Wrocławskiej Ser. SPR 2, 24 (in Polish)

Przylibski TA, Bartak J, KochowskaFijałkowska-Lichwa EL, Kozak K, Mazur J (2010) New SRDN-3 probes with a semi-conductor detector for measuring radon activity concentration in underground spaces. J Radioanal Nucl Chem 289:599-609 
Przylibski TA, Fijałkowska-Lichwa L, Kasza D (2017) Research of ${ }^{222} \mathrm{Rn}$ activity concentrations in the air of underground workings of the planned tourist route at Książ. Part 1. Raporty Wydziału Geoinżynierii, Górnictwa i Geologii Politechniki Wrocławskiej Ser. SPR, 1, 23 (in Polish)

Przylibski TA, Kaczorowski M, Fijałkowska-Lichwa L, Kasza D, Zdunek R, Wronowski R (2020) Testing of ${ }^{222} \mathrm{Rn}$ application for recognizing tectonic events observed on water-tube tiltmeters in underground Geodynamic Laboratory of Space Research Centre at Książ (the Sudetes, SW Poland). Appl Radiat Isot 163:108967. https://doi.org/10.1016/J.Apradiso.2019.108967

Richon P, Perrier F, Sabroux JC, Trique M, Ferry C, Voisin V, Pili E (2005) Spatial and time variations of radon-222 concentration in the atmosphere of a dead-end horizontal tunnel. J Environ Radioact 78:179-198

Shahrokhi A, Vigh T, Németh C, Csordás A, Kovács T (2017) Radon measurements and dose estimate of workers in a manganese ore mine. Appl Radiat Isot 124:32-37

Skowronek J, Wysocka M, Giebel M (2004) Radon in the caves of Jura Krakowsko-Częstochowska. Górnictwo i Środowisko Kwartalnik 3:77-87 (in Polish)

Strzelecki R, Wołkowicz S, Szewczyk J, Lewandowski P (1993) Radioecological maps of Poland. Part I: gamma radiation dose rates in Poland: map of caesium concentrations in Poland, scale 1: 750 000. Państwowy Instytut Geologiczny, Warszawa (in Polish)

Strzelecki R, Wołkowicz S, Szewczyk J, Lewandowski P (1994) Radioecological maps of Poland. Part II: map of uranium, thorium, and potassium concentrations in Poland. Państwowy Instytut Geologiczny, Warszawa (in Polish)

Tchorz-Trzeciakiewicz DE, Parkitny T (2015) Radon as a tracer of daily, seasonal and spatial air movements in the underground tourist route "coal mine" (SW Poland). J Environ Radioact 149:90-98

Tchorz-Trzeciakiewicz DE, Solecki AT (2011) Seasonal variation of radon concentrations in atmospheric air in the Nowa Ruda area (Sudety Mountains) of southwest Poland. Geochem J 45:455-461

Teisseyre H (1956) The Świebodzice depression is a geological unit. Biul Inst Geol 106:1-60 (in Polish)

Trevisi R, Orlando C, Orlando P, Amici M, Simeoni C (2012) Radon levels in underground workplaces results of a nationwide survey in Italy. Radiat Meas 47:178-181

UNSCEAR (2000) United Nations Scientific Committee on the Effects of Atomic Radiation. Sources and effects of ionizing radiation. Report to the general assembly with scientific annexes. United Nations, New York

UNSCEAR (2019) United Nations Scientific Committee on the Effects of Atomic Radiation. Sources and effects of ionizing radiation.
Report to the general assembly with scientific annexes. United Nations, New York

Vaupotič J (2008) Comparison of various methods of estimating radon dose at underground workplaces in wineries. Radiat Environ Biophys 47:527-534. https://doi.org/10.1007/s00411-008-0174-z

Vaupotič J, Csige I, Radolić V, Hunyadi I, Planinić J, Kobal I (2001) Methodology of radon monitoring and dose estimates in Postojna Cev, Slovenia. Health Phys 80(2):142-147

Walczak K, Olszewski J, Politański P, Zmyślony M (2017) Occupational exposure to radon for underground tourist routes in Poland: doses to lung and the risk of developing lung cancer. Int J Occup Med Environ Health 30(5):687-694. https://doi.org/10.13075/ Ijomeh.1896.00987

Wang YY, Luo W, Zeng G, Wang Y, Yang H, Wang M, Zhang L, Cai $X$, Chen J, Cheng A, Wang S (2019) High ${ }^{222}$ Rn concentrations and dynamics in Shawan Cave, Southwest China. J Environ Radioact 199-200:16-24

WHO (2009) World Health Organization. In: Zeeb H, Shannoun F (eds) Handbook on indoor radon: a public health perspective

Wojewoda J (2016a) The Świebodzice Unit (Sudety Mts.) —Structural anomalies during river valleys. In: VI Polska Konferencja Sedymentologiczna POKOS 6-“Granice Sedymentologii”. ChęcinyRzepka. 28.06.2016-1.07.2016, Tom Streszczeń, pp 145-148 (in Polish)

Wojewoda J (2016b) On the need for the second edition of the 'detailed geological map of the Sudetes' in 1:25 000 scale-examples of a revised description of geological structure based on a lidar background for a numerical model of the terrain surface. Prz Geol 64(9):597-603 (in Polish)

Wołkowicz S (ed) (2007) Radon potential of the Sudetes and selected geological units of the Fore-Sudetic block. In: Potencjał radonowy Sudetów wraz z wyznaczeniem obszarów występowania potencjalnie leczniczych wód radonowych. Rozdział 1. Państwowy Instytut Geologiczny, Warszawa (in Polish)

Wysocka M (2011) Radon in jurassic caves of the Kraków-Częstochowa Upland. Geochem J 45:447-453

Youssef M, Hanfi M (2019) Radiological assessment of gamma and radon dose rates at former uranium mining tunnels in Egypt. Environ Earth Sci 78:113. https://doi.org/10.1007/s12665-019-8089-3

Zhou Q, Liu S, Xu L, Zhang H, Xiao D, Deng J, Pan Z (2019) Estimation of radon release rate for an underground uranium mine ventilation shaft in China and radon distribution characteristics. J Environ Radioact 198:18-26

Publisher's Note Springer Nature remains neutral with regard to jurisdictional claims in published maps and institutional affiliations. 